\title{
Genomic and Evolutionary Features of the SPI-1 Type III Secretion System That Is Present in Xanthomonas albilineans but Is Not Essential for Xylem Colonization and Symptom Development of Sugarcane Leaf Scald
}

\author{
Mélanie Marguerettaz, ${ }^{1}$ Isabelle Pieretti, ${ }^{1}$ Philippe Gayral, ${ }^{1}$ Jérôme Puig, ${ }^{1}$ Chrystelle Brin, ${ }^{2}$ \\ Stéphane Cociancich, ${ }^{1}$ Stéphane Poussier, ${ }^{2}$ Philippe Rott, ${ }^{1}$ and Monique Royer ${ }^{1}$ \\ ${ }^{1}$ UMR BGPI CIRAD, Campus International de Baillarguet, TA A-54/K, 34398 Montpellier Cedex 5, France; ${ }^{2}$ UMR PaVé \\ Agrocampus ouest, BP 60057, 42 rue Georges Morel, 49071 Beaucouzé Cedex, France
}

Submitted 24 August 2010. Accepted 12 October 2010.

\begin{abstract}
Xanthomonas albilineans is the causal agent of sugarcane leaf scald. Interestingly, this bacterium, which is not known to be insect or animal associated, possesses a type III secretion system (T3SS) belonging to the injectisome family Salmonella pathogenicity island 1 (SPI-1). The T3SS SPI-1 of $X$. albilineans shares only low similarity with other available T3SS SPI-1 sequences. Screening of a collection of 128 plant-pathogenic bacteria revealed that this T3SS SPI-1 is present in only two species of Xanthomonas: $X$. albilineans and $X$. axonopodis pv. phaseoli. Inoculation of sugarcane with knockout mutants showed that this system is not required by $X$. albilineans to spread within xylem vessels and to cause disease symptoms. This result was confirmed by the absence of this T3SS SPI-1 in an X. albilineans strain isolated from diseased sugarcane. To investigate the importance of the T3SS SPI-1 during the life cycle of $X$. albilineans, we analyzed T3SS SPI-1 sequences from 11 strains spanning the genetic diversity of this species. No nonsense mutations or frameshifting indels were observed in any of these strains, suggesting that the T3SS SPI-1 system is maintained within the species $X$. albilineans. Evolutionary features of T3SS SPI-1 based on phylogenetic, recombination, and selection analyses are discussed in the context of the possible functional importance of T3SS SPI1 in the ecology of $X$. albilineans.
\end{abstract}

The Xanthomonadaceae are a family of gram-negative bacteria belonging to the order Xanthomonadales in the gamma subdivision of the Proteobacteria (Saddler and Bradbury 2005). Members of this family occupy diverse ecological niches in soil and water, as well as being present in plant tissues. Many Xanthomonadaceae, especially species from the genera Xanthomonas and Xylella, cause plant diseases, and

Corresponding author: M. Royer; Telephone: +33 (0) 4996248 44; Fax: +33 (0) 4996248 08; E-mail: monique.royer@cirad.fr

Current address of P. Gayral; Institut des Sciences de l'Evolution, CNRS UMR 5554, Université Montpellier 2, Place E. Bataillon, 34095 Montpellier, France.

* The $\boldsymbol{e}$-Xtra logo stands for "electronic extra" and indicates that four supplementary tables and three supplementary figures are published online. one species, Stenotrophomonas maltophilia, is known to be an opportunistic human pathogen.

Xanthomonas albilineans is a systemic, xylem-invading pathogen that causes leaf scald - a lethal disease of sugarcane (interspecific hybrids of Saccharum spp.) (Rott and Davis 2000). Leaf scald symptoms vary from a single, sharply defined narrow white stripe to complete wilting and necrosis of infected leaves leading to plant death. The pathogen is transmitted mainly by infested tools and infected sugarcane cuttings. $X$. albilineans is not known to be insect transmitted but there is evidence of aerial transmission under certain environmental conditions (Champoiseau et al. 2009; Daugrois et al. 2003; Davis et al. 1997; Saumtally et al. 1996). The only pathogenicity factor of $X$. albilineans that has been studied extensively to date is albicidin - a secreted small molecule with phytotoxic and antibiotic properties (Birch 2001). Albicidin is a potent DNA gyrase inhibitor that targets chloroplastic DNA gyrase A, inhibits chloroplast DNA replication, and blocks chloroplast differentiation, resulting in the white foliar stripe symptom (Birch 2001; Hashimi et al. 2007).

Type III secretion systems (T3SS), also called injectisomes, produce nanomachines that deliver effector proteins specifically into the cytoplasm of host cells. These effectors then target key functions of the host, thus explaining the major role played by T3SS in pathogenesis and symbiosis (Cornelis 2006; He et al. 2004; Lewis et al. 2009; Saijo and Schulze-Lefert 2008). The mechanisms whereby T3SS effectors interact with host cells have been well documented for animal-infecting bacteria and plant pathogens (Croxen and Finlay 2010; Kay and Bonas 2009; McGhie et al. 2009). Evolutionary trees of injectisome T3SS gene clusters are completely different from bacterial evolutionary trees based on $16 \mathrm{~S}$ rRNA analysis (Gupta 2000), implying that T3SS gene clusters have been distributed among bacteria through lateral gene transfer. Based on phylogenetic analyses, T3SS were divided into seven families (Cornelis 2006), including three that are found mainly in freeliving animal pathogens (Yersinia secretion [Ysc] and Salmonella pathogenicity islands 1 and 2 [SPI-1 and SPI-2, respectively]) and two that occur mainly in plant-invading bacteria (hypersensitive response and pathogenicity 1 and 2 [Hrp1 and Hrp2, respectively]). The global architecture of the structural components within the bacterial membrane is well conserved among the different T3SS families. However, the length of the 
pilus that extends from the basal structure varies from 40 to 80 $\mathrm{nm}$ in animal pathogens (T3SS SPI-1, SPI-2, or Ysc) and up to several microns in plant-invading bacteria (T3SS Hrp1 or Hrp2), allowing it to protrude into the thick plant cell wall (Cornelis 2006).

Recent sequencing of the complete genome of $X$. albilineans GPE PC73 confirmed the absence of a T3SS of the Hrp1 or Hrp2 type but revealed the presence of T3SS SPI-1 (Pieretti et al. 2009). T3SS SPI-1, which is found mostly in bacteria associated with mammals or insects, also occurs in four plantinvading bacteria: Erwinia amylovora Ea273 (the causal agent of fire blight of apple, pear, and related plants), E. tasmaniensis Et1/99 (a strictly epiphytic bacterium isolated from apple flowers), E. pyrifoliae (the causal agent of black stem blight of pear), and Pantoea stewartii subsp. stewartii (the causal agent of Stewart's wilt of maize) (Correa et al. 2010; Kube et al. 2008, 2010; Sebaihia et al. 2010; Smits et al. 2010). Moreover, three DNA fragments of a putative T3SS SPI-1 were disclosed by subtractive hybridization in strains belonging to one (lineage 1) of the four genetic lineages of $X$. axonopodis pv. phaseoli (the causal agent of common bacterial blight of bean) (Alavi et al. 2008). Similarly, T3SS Ysc, which is found preferentially in animal pathogens, has also been found in the genome of the plant pathogen Pseudomonas syringae pv. phaseolicola 1448A (the causal agent of halo blight disease in common bean) (Joardar et al. 2005). The role of T3SS SPI-1 or Ysc in these plant-invading bacteria remains unknown but it could be hypothesized that T3SS SPI-1 or Ysc is required for interaction of these plant-invading bacteria with an insect or an animal. In Pantoea stewartii subsp. stewartii, it was shown recently that T3SS SPI-1 was required for persistence in its flea beetle vector, Chaetocnema pulicaria, whereas T3SS Hrp was involved in plant colonization (Correa et al. 2010).

The objectives of the present study were to i) perform a functional analysis of the T3SS SPI- 1 of X. albilineans in order to confirm that this system is not required for sugarcane infection, ii) analyze the distribution of this T3SS SPI-1 within a collection of plant-pathogenic bacteria, and iii) analyze the genetic diversity of the T3SS SPI-1 gene cluster within the species $X$. albilineans in order to shed some light on its functional importance during the life cycle of the causal agent of sugarcane leaf scald.

\section{RESULTS}

\section{The genome of $X$. albilineans GPE PC73 harbors a T3SS SPI-1.}

Annotation of the genome of $X$. albilineans GPE PC73 revealed the presence of a T3SS similar to the $b s a$ T3SS of several Burkholderia spp. (e.g. bsa T3SS of Burkholderia pseudomallei, which belongs to the injectisome family SPI-1 and is a causal factor in human melioidosis) (Stevens et al. 2002). In $X$. albilineans GPE PC73, T3SS SPI-1 is present in a region of $43.6 \mathrm{~kb}$ flanked by IS elements and which has an overall $\mathrm{G}+\mathrm{C}$ base composition (52\%) lower than that of the rest of the genome $(63 \%)$. Both these latter features suggest that the $43.6-\mathrm{kb}$ region represents a genetic island acquired by lateral gene transfer. This region is located next to the albicidin biosynthesis gene cluster near the terminus of replication (Pieretti et al. 2009). Phylogenetic reconstruction using a concatenation of six T3SS SPI-1 structural proteins from bacteria associated with mammals, insects, or plants showed that the T3SS SPI-1 of $X$. albilineans belongs to the same phylogenetic group as the T3SS SPI-1 present in the plant-invading bacteria E. tasmaniensis, E. amylovora, E. pyrifoliae, and Pantoea stewartii subsp. stewartii (Fig. 1, group A). All B. pseudomallei genes encoding the components of the SPI-1 injectisome and translo- con are conserved in $X$. albilineans (Fig. 2; Table 1). Genes required for injectisome assembly were annotated with reference to their $b s a$ orthologous genes in Burkholderia spp. (xsaJ, $x s a K, x s a L, x s a M, x s a O, x s a P, x s a Q, x s a R, x s a S, x s a V, x s a W$, $x s a X, x s a Y$, and $x s a Z$ ) (Fig. 2). Genes encoding components of the SPI-1 translocon were annotated $x i p B$, xipC, and xipD with reference to their bip and sip orthologous genes in the genera Burkholderia and Salmonella, respectively. The B. pseudomallei gene $b s a N$, which encodes a transcriptional regulator of the AraC family, is conserved in $X$. albilineans, in which it was annotated as $x s a N$. B. pseudomallei gene bicA (encoding a chaperone protein) is also conserved in $X$. albilineans (annotated as $x i c A$ ). Two B. pseudomallei genes encoding putative oxygen-regulated invasion proteins are also conserved in $X$. albilineans, and were annotated as $\operatorname{org} A$ and $\operatorname{org} B$. Interestingly, B. pseudomallei genes $b s a T$ and $b s a U$, which are specific to T3SS SPI-1 of Burkholderia spp., are not conserved in X. albilineans. B. pseudomallei genes encoding T3SS SPI-1 effectors are also not conserved in $X$. albilineans. BLAST analyses with the entire genome of $X$. albilineans confirmed that this species does not possess any of the known T3SS secreted effectors (T3SEs). However, T3SS SPI-1 of X. albilineans GPE PC73 encodes 15 hypothetical proteins specific to this species that represent candidate T3SEs. In other T3SS SPI-1 described to date, several genes encoding T3SEs are present in the same genetic island as the genes encoding structural components. Genes encoding candidate T3SEs SPI-1 of X. albilineans were annotated as Xanthomonas-associated protein (xap)A through $x a p O$. The presence of an F-box-like domain in the hypothetical protein encoded by $x a p N$ supports the hypothesis that this protein is a T3SE because such a domain was described in T3SEs of Ralstonia solanacearum (Angot et al. 2006). The similarity of the hypothetical protein encoded by $x a p M$ with the toxin RtxA of Photorhabdus luminescens is also evidence that this protein may be a T3SE.

\section{Screening of 128 plant-pathogenic bacteria for the presence of T3SS SPI-1.}

It was shown recently by subtractive hybridization that strains belonging to lineage 1 of $X$. axonopodis pv. phaseoli harbor at least three DNA fragments encoding putative components of a T3SS SPI-1 (Alavi et al. 2008). These fragments share $>85 \%$ nucleotide identity and $83 \%$ amino acid identity with the sequence of the T3SS SPI- 1 gene cluster of $X$. albilineans. To determine whether the T3SS SPI-1 gene cluster was fully or partially present in X. axonopodis pv. phaseoli strains, we used 35 primer pairs designed to amplify the complete T3SS SPI-1 from $X$. albilineans (Supplementary Table 1). Polymerase chain reaction (PCR) products of the expected size were obtained with only eight primer pairs (T3SS 6, 9, 13, $14,15,17,18$, and 22) in three $X$. axonopodis pv. phaseoli strains (CFBP 2534, CFBP 6164, and CFBP 6982). Sequencing of these PCR products revealed between 77 and $87 \%$ nucleotide identity with the sequence of the T3SS SPI-1 of $X$. albilineans. Moreover, no nucleotide diversity was seen between the three tested $X$. axonopodis pv. phaseoli strains. The amplified PCR products correspond to genes required for injectisome assembly (xsaJ, xsaK, xsaL, xsaM, xsaO, xsaP, xsaR, $x s a W, x s a X$, or $x s a Y$ ) and one gene encoding a component of the SPI-1 translocon (xipB). However, other T3SS SPI-1 genes, including xipD and candidate T3SEs genes, were not detected by PCR in any strain of $X$. axonopodis pv. phaseoli.

To see whether this T3SS SPI-1 gene cluster is indeed restricted to only two xanthomonads ( $X$. albilineans and $X$. axonopodis pv. phaseoli), a collection of 128 strains representing the main genera of plant-pathogenic bacteria (Supplementary Table 2) was screened by PCR and dot-blot hybridization. Both 
methods yielded the same result and revealed that the distribution of T3SS SPI-1 is very restricted. Indeed, no DNA fragments homologous to T3SS SPI-1 were detected in any of the 128 strains, with the exception of the 14 strains belonging to $X$. albilineans and genetic lineage 1 of $X$. axonopodis pv. phaseoli (Supplementary Fig. 1).
Is T3SS SPI-1 required

for $X$. albilineans to infect sugarcane and cause symptoms?

Sugarcane cv. CP68-1026 was inoculated with wild-type strain GPE PC73 R5 and three $x \mathrm{saO}$ mutants of GPE PC73 R5 (six plants inoculated per strain at $10^{8} \mathrm{CFU} / \mathrm{ml}$ ). Detailed results are presented in Supplementary Figure 2. Within 2 to 4

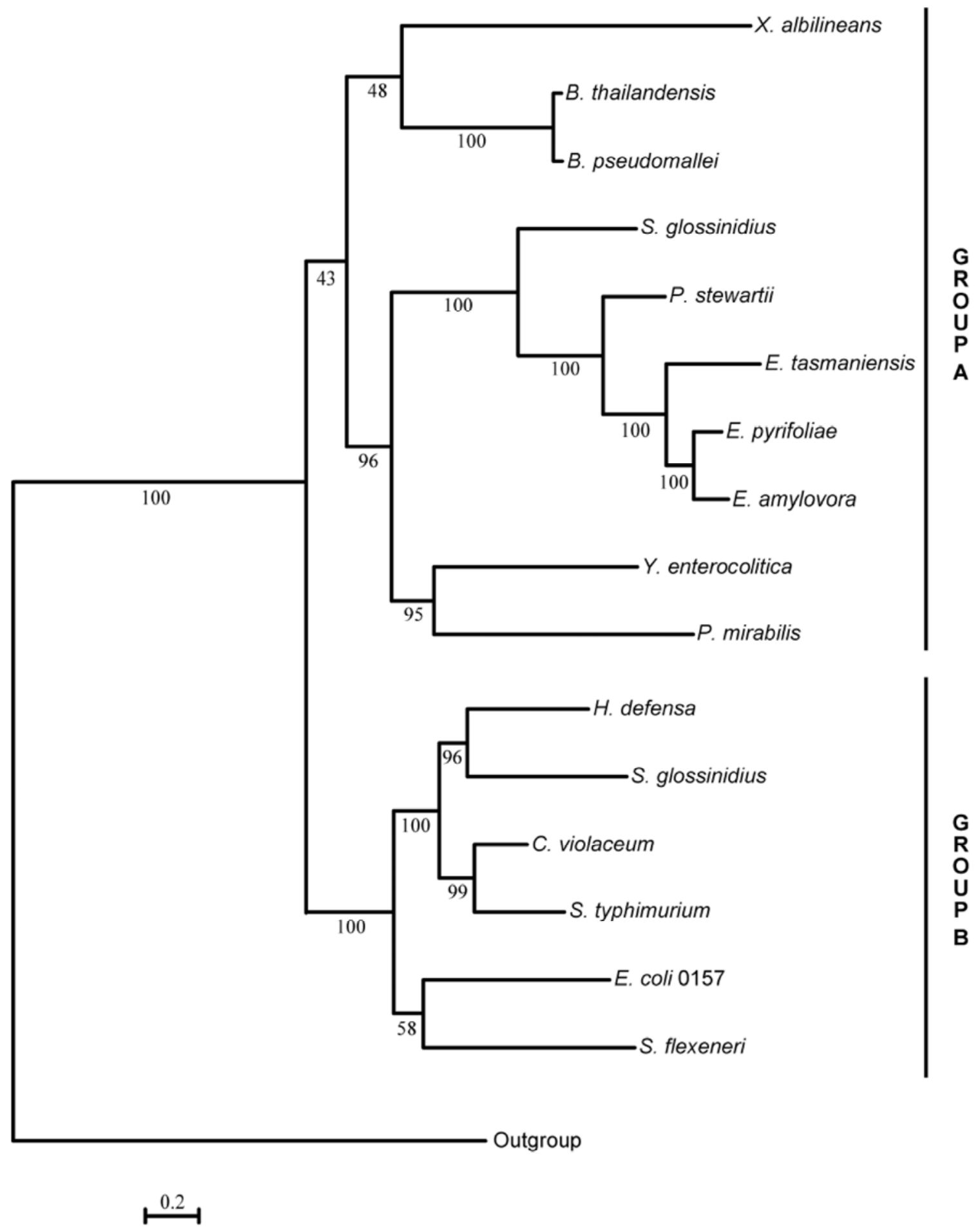

Fig. 1. Tree of the concatenated amino acid sequence of six type III secretion system (T3SS) Salmonella pathogenicity island 1 (SPI-1) structural proteins from bacteria associated with mammals (Burkholderia pseudomallei, B. thailandensis, Yersinia enterocolitica, Chromobacterium violaceum, Salmonella typhimurium, Escherichia coli 0157:H7, Shigella flexeneri, and Proteus mirabilis), insects (Sodalis glossinidius and Hamiltonella defensa), or plants (Xanthomonas albilineans, Erwinia tasmaniensis, E. amylovora, E. pyrifoliae, and Pantoea stewartii subsp. stewartii) using the maximum likelihood method and LG as the substitution model. Six T3SS SPI-1 structural proteins were used in this analysis in X. albilineans: XsaS/InvC/SpaI, XsaP/InvE/MxiC, $\mathrm{XsaQ/InvA/MxiA,} \mathrm{XsaX/SpaQ,} \mathrm{XsaZ/SpaS,} \mathrm{and} \mathrm{XsaY/InvN/SpaR.} \mathrm{The} \mathrm{tree} \mathrm{was} \mathrm{constructed} \mathrm{with} \mathrm{sequences} \mathrm{of} \mathrm{the} \mathrm{T3SS} \mathrm{SPI-2} \mathrm{structural} \mathrm{proteins} \mathrm{of} B$. pseudomalle $i$ and $H$. defensa as an outgroup. Bootstrap percentages retrieved in 500 replications are shown at the nodes. The scale bar (0.2) indicates the number of nucleotide substitutions per site. 
weeks, the wild-type strain and all three mutants produced pencil-line stripes characteristic of leaf scald symptoms on inoculated leaves. On average, 8 stripes per inoculated leaf were observed with strain GPE PC73 R5, whereas the average number of stripes varied between 8 and 10 for the three $x \mathrm{saO} \mathrm{mu-}$ tants (18 leaves observed per strain). In the six plants inoculated with the wild-type strain, 16 of $19(84 \%)$ sampled stalk internodes were colonized by the pathogen. In plants inoculated with the three $x \mathrm{saO}$ mutants, the pathogen was recovered in 15 of $20(75 \%), 15$ of $19(79 \%)$, and 21 of $23(91 \%)$ sampled stalk internodes, respectively. Thus, the capacity of the $x \mathrm{saO}$ mutants to spread through sugarcane xylem and cause leaf symptoms was similar to that of the wild-type strain.

\section{Sequencing of the T3SS SPI-1 gene cluster from $X$. albilineans Xa23R1.}

A 56-kb DNA region containing the complete albicidin biosynthesis gene cluster from $X$. albilineans Xa23R1 was previously sequenced (Royer et al. 2004). This region also included the five hypothetical protein genes $x a p M, x a p L, x a p K, x a p J$, and xapI. The rest of the T3SS SPI-1 gene cluster, which corresponds to a 37-kb region, was amplified by PCR from strain Xa23R1, with primers generating 35 overlapping PCR fragments (Fig. 2C). Assembling the sequences of the PCR fragments and the previously sequenced $56-\mathrm{kb}$ region reconstituted the sequence of the entire T3SS SPI-1 gene cluster from $X$. albilineans Xa23R1 (Fig. 2C). All genes identified in strain GPE PC73 are conserved in strain Xa23R1. The most notable differences between the two sequences are i) an internal deletion of $30 \mathrm{nt}$ in $x a p H$ of Xa23R1; ii) a mutation in the start codon of $x a p B$ making the open reading frame (ORF) $45 \mathrm{nt}$ shorter in Xa23R1; and iii) the presence, upstream of a sequence similar to bipD of $B$. pseudomallei, of two different sequences of 963 and 1,143 bp in GPE PC73 and Xa23R1, respectively. These two latter sequences showed no significant alignment with any nucleotide or amino acid sequence available in GenBank. Further analysis of these two unique sequences suggested that the XipD translocase proteins encoded by $X$. albilineans strains GPE PC73 and Xa23R1 each have their own unique features (Fig. 3). In both strains, the sequence similar to bipD is present in an ORF that is much longer $(1,881$ and 2,061 bp in strains GPE PC73 and Xa23R1, respectively) than orthologous genes described to date in other T3SS SPI-1 ( 855 to $1,020 \mathrm{bp}$ ). The first $363 \mathrm{bp}$ of the xipD ORF of strains GPE PC73 and Xa23R1 are 98\% identical and did not align significantly with any amino acid sequence available in GenBank. The last 555 bp of these xipD ORF are also $98 \%$ identical and exhibit 58\% amino acid similarity with the orthologous gene bipD of B. pseudomallei (Fig. 3). The strain-specific internal sequences of 963 and 1,143 bp exhibit 37\% amino acid identity and 59\% amino acid similarity (Fig. 3; Supplementary Fig. 3), suggesting that the two allelic forms of xipD

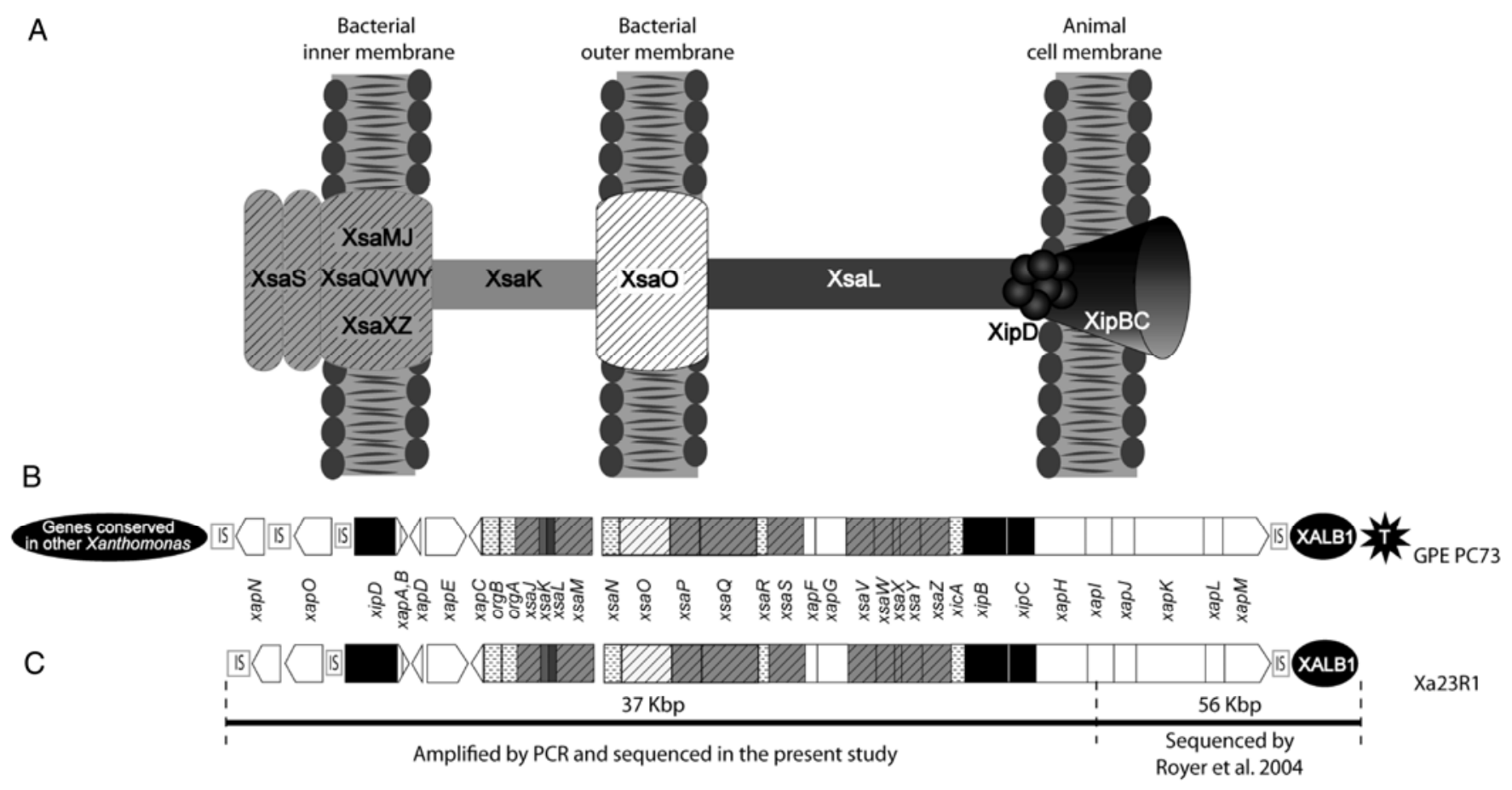

Fig. 2. A, Schematic illustration of the structure of type III secretion system (T3SS) Salmonella pathogenicity island 1 (SPI-1) of Xanthomonas albilineans. The putative locations of $X$. albilineans proteins are based on the function proposed for the corresponding homologous structural proteins of Salmonella enterica (Gerlach and Hensel 2007). The X. albilineans proteins and their respective homologous proteins in $S$. enterica are XsaS/InvC, XsaM/PrgH, XsaJ/PrgK, XsaQ/InvA, XsaV/InvK, XsaW/InvL, XsaY/InvN, XsaX/SpaQ, XsaZ/SpaS, XsaK/PrgJ, XsaO/InvG, XsaL/PrgI, XipD/SipD, XipB/SipB, and XipC/SipC. B, Genomic organization of the T3SS SPI-1 gene cluster in X. albilineans GPE PC73. All genes depicted within a single block are in the same orientation (indicated by the arrow at the end of the last gene of each box). Gene names are indicated below the boxes. Putative gene functions: black boxes = translocon components, gray hatched boxes = products associated with inner membrane, light gray box = product associated with both inner and outer membranes, dark gray box = product associated with external syringe (needle), white hatched box = product associated with outer membrane. White boxes with horizontal dashes indicate other genes conserved in Burkholderia pseudomallei: putative chaperone protein genes (xicA and xsaR), putative regulatory protein gene $(x s a N)$, and putative oxygen-regulated invasion protein genes ( $\operatorname{org} A$ and $\operatorname{org} B$ ). Empty white boxes indicate hypothetical protein genes (candidate-secreted T3SS SPI-1 effectors = T3SEs). The label "Genes conserved in other Xanthomonas" on the left indicates genes present upstream from the first insertion sequence and which are conserved in other Xanthomonas spp. C, Genomic organization of the T3SS SPI-1 gene cluster in X. albilineans Xa23R1. Boxes defined as in B. Parts of the T3SS SPI-1 previously sequenced by Royer and associates (2004) or amplified by polymerase chain reaction and sequenced in the present study are indicated at the bottom of the figure. IS = insertion sequence; XALB1 = albicidin biosynthesis gene cluster (Royer et al. 2004). $\mathrm{T}=$ replication terminus. Adapted from Guttman and associates (2006). 
are derived from the same ancestor gene and have a similar and unique function. Additionally, the $184 \mathrm{bp}$ upstream of the two allelic forms of xipD are $97 \%$ identical, indicating that transcriptional regulatory sequences are conserved in both $X$. albilineans strains. The two allelic forms of xipD were designed $x i p D-G$ for GPE PC73 and $x i p D-X$ for Xa23R1.

\section{Phylogenetic and recombination analyses of T3SS SPI-1 sequences \\ from different strains of $X$. albilineans.}

Sequence analyses were performed with a collection of 12 strains representative of the genetic diversity of $X$. albilineans previously identified using pulsed-field gel electrophoresis (PFGE) (Davis et al. 1997). Strains Xa23R1, GPE PC73, HVO082, REU173, FIJ080, HVO005, LKA070, PNG130, MTQ058, and REU209 belong to PFGE groups A, B, C, D, E, F, G, H, I, and J, respectively (Supplementary Table 3). Because strains involved in sugarcane leaf scald disease outbreaks since the late 1980s belong to group PFGE-B, two additional strains belonging to this group were included in our analysis (strains MTQ078 and BRA115). To study evolution of the core genome, multilocus sequence analysis (MLSA) was performed using a concatenated sequence of PCR fragments of seven housekeeping genes ( $g r o E L$, dnaK, gyrB, atpD, efp, recA, and $g \ln A$ ) (Fig. 4). To study evolution of the T3SS SPI-1 gene cluster, five fragments were amplified by PCR: i) the large ORF xipD, except its $3^{\prime}$ part; ii) the $3^{\prime}$ part of xipD and complete sequence of $x a p A$ and $x a p B$; iii) partial sequence of $x s a M$, iv) partial sequence of $x s a O$; and v) partial sequence of $x a p H$, including the 30-nt deletion observed in Xa23R1 (Fig. 5B). No PCR product was obtained for strain PNG130, which probably lost T3SS SPI-1. All five PCR fragments were amplified from all other strains. Sequences of these PCR fragments were compared with the corresponding sequence of strains GPE PC73 and Xa23R1, allowing analysis of 11 strains in all. Interestingly, ORF xipD is present in all 11 strains but the distribution of the allelic forms $x i p D-G$ or $x i p D-X$ was not congruent with the core genome MLSA tree, suggesting the occurrence of recombination events (Fig. 4). To explain this unexpected result, recombination analyses were performed with different algorithms (CHIMAERA, Recombination Detection Program [RDP], GENECONV, and DNA Sequence Polymorphism [DnaSP]) using a concatenated sequence of the five PCR fragments (Fig. 5B) for each of the 11 strains. Several recombination events were predicted with high probability ( $P$ values varying from $1 \times 10^{-6}$ to $8 \times 10^{-40}$ ) (Fig. 5C), not only at the xipD locus but also along the entire concatenated sequence. Similar phylogenetic analyses were also conducted with these 11 strains using the entire coding sequences of xipD, xapA, and $x a p B$ and partial coding sequences of $x s a M, x s a O$, and $x a p H$. The coding sequence of $x i p D$ was divided into three parts that were analyzed separately: $x i p D / a$ corresponds to the $5^{\prime}$ part of xipD shared by strains GPE PC73 and Xa23R1, xipD/b corresponds to the internal sequence specific to each allelic form (xipD-G and $x i p D-X$ ), and $x i p D / c$ corresponds to the sequence similar to bipD that is common to strains GPE PC73 and Xa23R1 (Fig. 3). Two distinct phylogenetic clades (clade 1 and clade 2) were obtained for each of the seven coding sequences used for phylogenetic analyses (xipD/a, xipD/c, xapA, $x a p B, x s a M, x s a O$, and $x a p H$ ) (Fig. 4). The distribution of the 11 strains in clade 1 or clade 2 differed according to the sequence used for phylogenetic analyses (Fig. 4). For example, strains GPE PC73 and LKA070, which possess two different allelic forms of xipD, are in the same clade (clade 1) in trees constructed with $x i p D / a, x a p B, x s a M$, xsaO, and $x a p H$ but in different clades in trees constructed with $x i p D / c$ and $x a p A$. Similarly, strains FIJ080 and Xa23R1, which also possess two different allelic forms of xipD, are in the same clade (clade 2) in trees constructed with xipD/a, xapA, xsaM, and $x a p H$ but in different clades in trees constructed with $x i p D / c$ and $x s a O$. Distribution of the 11 strains in phylogenetic trees obtained with housekeeping genes (core genome) or coding sequences $x s a O, x a p A, x i p D / b$, and $x i p D / c$ also provided evidence of recombination events (Fig. 5D). The existence of only two allelic forms of xipD (xipD-G and xipD-X) (Fig. 3) and the distribution of T3SS SPI-1 sequences in only two clades (clade 1 and clade 2) (Fig. 4) indicate that recombination events have mobilized only two ancestral alleles of T3SS SPI-1.

Table 1. Comparative analysis of type III secretion system Salmonella pathogenicity island 1 (SPI-1) genes conserved in Xanthomonas albilineans and Burkholderia pseudomallei

\begin{tabular}{|c|c|c|c|c|c|c|c|c|}
\hline \multirow[b]{2}{*}{ Putative function } & \multirow[b]{2}{*}{ Nomenclature $^{a}$} & \multicolumn{3}{|c|}{ X. albilineans (strain GPE PC73) } & \multicolumn{3}{|c|}{ B. pseudomallei (strain K96243) } & \multirow[b]{2}{*}{ Identity $(\%)^{\mathrm{c}}$} \\
\hline & & Accession & Protein & Length $^{b}$ & Accession & Protein & Length $^{b}$ & \\
\hline Injectisome component & PrgK/MxiJ & XALc_1486 & XsaJ & 295 & BPSS 1550 & BsaJ & 316 & $100 / 181(55)$ \\
\hline Injectisome component & PrgJ & XALc_1487 & XsaK & 94 & BPSS 1549 & BsaK & 100 & $20 / 73(27)$ \\
\hline Injectisome component & PrgI/MxiH & XALc_1488 & XsaL & 97 & BPSS 1548 & BsaL & 89 & $44 / 90(48)$ \\
\hline Injectisome component & $\mathrm{PrgH}$ & XALc_1489 & XsaM & 467 & BPSS 1547 & BsaM & 428 & $115 / 441(26)$ \\
\hline Regulation & InvF & XALc_1490 & $\mathrm{XsaN}$ & 210 & BPSS 1546 & BsaN & 252 & $73 / 165$ (44) \\
\hline Injectisome component & InvG/MxiD & XALc_1491 & $\mathrm{XsaO}$ & 626 & BPSS1545 & $\mathrm{BsaO}$ & 606 & $234 / 562(41)$ \\
\hline Injectisome component & InvE/MxiC & XALc_1492 & XsaP & 371 & BPSS 1544 & BsaP & 373 & $115 / 371(30)$ \\
\hline Injectisome component & InvA/MxiA & XALc_1493 & XsaQ & 703 & BPSS 1543 & BsaQ & 690 & $369 / 701(52)$ \\
\hline Chaperone & InvB & XALc_1494 & XsaR & 136 & BPSS 1542 & BsaR & 135 & $32 / 135(23)$ \\
\hline Injectisome component & InvC/SpaI & XALc_1495 & $\mathrm{XsaS}$ & 449 & BPSS 1541 & BsaS & 436 & $221 / 445(49)$ \\
\hline Injectisome component & InvK/SpaO & XALc_1498 & $\mathrm{XsaV}$ & 346 & BPSS 1538 & BsaV & 327 & $71 / 266(26)$ \\
\hline Injectisome component & InvL/SpaP & XALc_1499 & XsaW & 231 & BPSS 1537 & BsaW & 226 & $119 / 227(52)$ \\
\hline Injectisome component & SpaQ & XALc_1500 & XsaX & 88 & BPSS 1536 & BsaX & 84 & $42 / 82(51)$ \\
\hline Injectisome component & InvN/SpaR & XALc_1501 & XsaY & 256 & BPSS 1535 & BsaY & 256 & $102 / 244(41)$ \\
\hline Injectisome component & SpaS & XALc_1502 & XsaZ & 358 & BPSS 1534 & BsaZ & 411 & $156 / 350(44)$ \\
\hline Hypothetical protein & OrgA & XALc_1485 & OrgA & 198 & BPSS 1551 & $\ldots$ & 195 & $52 / 186(27)$ \\
\hline Hypothetical protein & OrgB & XALc_1484 & OrgB & 220 & BPSS 1552 & $\ldots$ & 260 & $37 / 176(21)$ \\
\hline Chaperone & $\operatorname{SicA}$ & XALc_1503 & $\mathrm{XicA}$ & 171 & BPSS1533 & BicA & 171 & $80 / 166(48)$ \\
\hline Translocon component & SipB/IpaB & XALc_1504 & XipB & 534 & BPSS1532 & BipB & 620 & $131 / 375(34)$ \\
\hline Translocon component & SipC/IpaC & XALc_1505 & XipC & 348 & BPSS1531 & BipC & 419 & $68 / 263(25)$ \\
\hline Translocon component & SipD/IpaD & XALc_1477 & XipD & 626 & BPSS 1529 & BipD & 285 & $66 / 199(33)$ \\
\hline
\end{tabular}

\footnotetext{
${ }^{a}$ Frequently used nomenclature.

${ }^{\mathrm{b}}$ Length in amino acids.

c Amino acid identity.
} 
Selection analysis of T3SS SPI-1 coding sequences in 11 strains of $X$. albilineans.

Despite the occurrence of several recombination events, no nonsense mutations or frameshifting indels were observed in any of the five PCR fragments from nine $X$. albilineans strains or in the complete sequence of T3SS SPI-1 from strains GPE PC73 and Xa23R1. The 30-nt internal deletion in $x a p H$ found in strain Xa23R1 was not detected in any other strain; this deletion does not modify the coding phase and, thus, may not affect the function of $x a p H$. The mutation in the start codon of $x a p B$ in Xa23R1, which shortens the ORF by $45 \mathrm{nt}$, was also observed in strains HVO082, HVO005, and REU209. This codon, which was identified as a start codon by annotators of the genome of strain GPE PC73, is not preceded by a known ribosome binding site and is most likely not a real start codon. Thus, $x a p B$ may be $45 \mathrm{nt}$ shorter than previously thought in all $X$. albilineans strains. All T3SS SPI-1 genes are conserved in strains GPE PC73 and Xa23R1, which belong to two distinct core genome (MLSA) clades. All these data suggest that T3SS SPI-1 is still functional in all $11 \mathrm{X}$. albilineans strains.

Estimation of the $\omega=$ nonsynonymous to synonymous substitution $\left(d_{N} / d_{S}\right)$ ratio is usually used to quantify the selective pressure acting on genes. Genes evolving under no selective pressure evolve neutrally $(\omega=1)$, whereas genes evolving under selection pressure have $\omega \neq 1$. Purifying selection $(\omega<1)$ is observed when amino acid replacement is counterselected and positive selection $(\omega>1)$ occurs when amino acid replacement is favored by natural selection. We estimated the $\omega$ ratio for each coding sequence of the T3SS SPI-1 cluster retrievable from the five PCR fragments (Table 2). Four coding sequences (xipD/c, xapA, xapB, and $x s a M$ ) have an $\omega$ ratio ranging from 0.248 to 1.956 , which was not statistically different from 1 according to likelihood ratio tests (LRT) $(P$ value $=0.1512$, $0.2073,0.3638$, and 0.6825 , respectively) (Table 2$)$. Therefore, the corresponding genes are thought to have evolved neutrally, under no selection pressure. The coding sequences xipD/a and $x s a O$ have an $\omega$ ratio of 0.252 and 0.113 , respectively, which was statistically significant at $P<1(P$ value $=0.0158$ and $P$ value $<0.001$, respectively) (Table 2 ). This result suggests the presence of purifying selection (i.e., selection still acting on $x s a O$ and $x i p D / a$ to prevent amino acid replacement), indicating that the $5^{\prime}$ part of xipD (xipD/a) is translated in X. albilineans and supporting the hypothesis that xipD is longer than orthologous genes.

Unlike other analyzed T3SS SPI-1 coding sequences, $x a p H$ has an $\omega>1(\omega=4.552 ; P$ value $=0.0125)$ (Table 2$)$, suggesting that $x a p H$ evolved under positive selection. The presence of positive selection was analyzed in detail using a codon-bycodon approach (Table 3). Positive selection in a few codons of a sequence may increase the estimated average $\omega$ ratio for the whole gene, thus leading to an artefactual signature of neutral evolution. We observed that $x a p H$ evolved under positive selection $(P$ value $=0.044)$ and that no other genes of the

A

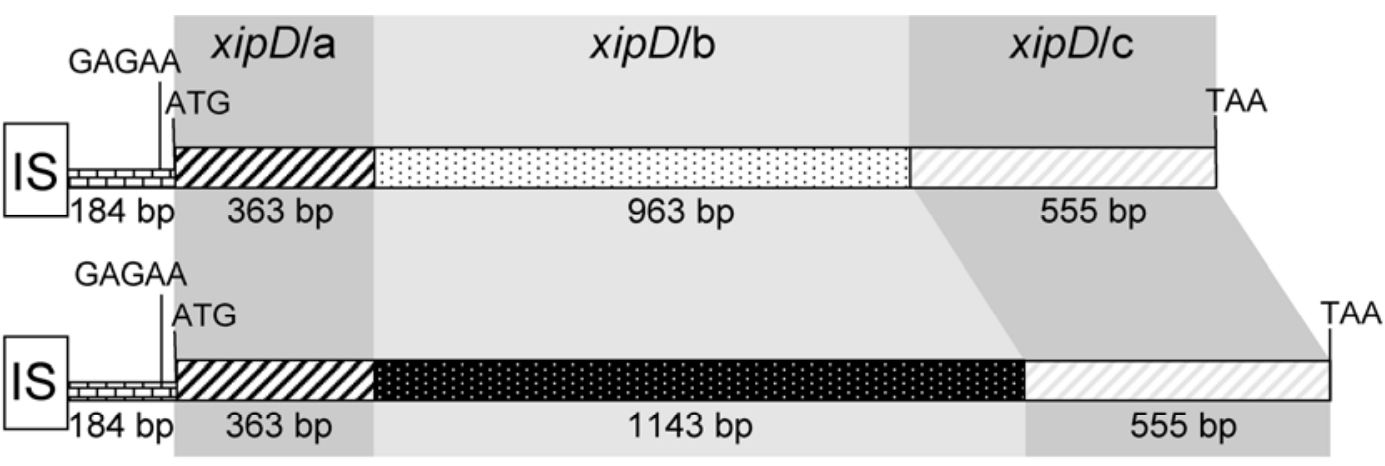

B Comparison of the two allelic forms of $x i p D$ present in $X$. albilineans strains GPE PC73 and Xa23R1

\begin{tabular}{|l|cccc|}
\hline Nucleotide identity & $97 \%$ & $98 \%$ & no significant & $98 \%$ \\
& $(178 / 184)$ & $(355 / 363)$ & alignment & $(546 / 555)$ \\
\hline Amino acid identity & & $96 \%$ & $37 \%$ & $98 \%$ \\
& $(116 / 121)$ & $(119 / 321)$ & $(181 / 185)$ \\
\hline \multirow{2}{*}{ Amino acid similarity } & & $96 \%$ & $59 \%$ & $99 \%$ \\
& & $(116 / 121)$ & $(189 / 321)$ & $(183 / 185)$ \\
\hline
\end{tabular}

C Comparison of $x i p D$ of $X$. albilineans (both allelic forms) with the orthologous bipD gene of $B$. pseudomallei

\begin{tabular}{|l|ccc|}
\hline Nucleotide identity & $\begin{array}{c}\text { no significant } \\
\text { alignment }\end{array}$ & $\begin{array}{c}\text { no significant } \\
\text { alignment }\end{array}$ & $\begin{array}{c}\text { no significant } \\
\text { alignment }\end{array}$ \\
\hline Amino acid identity & $\begin{array}{c}\text { no significant } \\
\text { alignment }\end{array}$ & $\begin{array}{c}\text { no significant } \\
\text { alignment }\end{array}$ & $35 \%$ \\
\hline Amino acid similarity & no significant & alignment & no significant \\
alignment & $56 / 185)$ \\
\hline
\end{tabular}

Fig. 3. A, Comparison of the physical maps of the allelic forms of xipD present in Xanthomonas albilineans strains GPE PC73 and Xa23R1. Black and gray hatched boxes indicate parts of coding sequence of xipD shared by both strains (parts called xipD/a and xipD/c, respectively). Gray hatched box (part xipD/c) indicates the part of xipD that is similar to the bipD gene of Burkholderia pseudomallei. White and black dotted boxes indicate the region of the coding sequence of xipD that is not shared by strains GPE PC73 and Xa23R1 (xipD/b). Boxes with bricks upstream of the ATG codon indicate the noncoding 5' region shared by strains GPE PC73 and Xa23R1. The lengths of the corresponding nucleotide sequences are indicated below each box. Putative start codon (ATG), stop codon (TAA), and a ribosome binding site (GAGAA) located 8 bp upstream of the start codon are indicated for the two allelic forms of xipD. IS $=$ insertion sequence. B, Data from BLAST alignments of the two allelic forms of xipD of strains GPE PC73 and Xa23R1. C, Data from BLAST alignments of the two allelic forms of $x i p D$ with the orthologous gene bipD of B. pseudomallei. Vertical gray zones indicate the three parts of coding sequence of $x i p D$ (xipD/a, xipD/b, and xipD/c). 


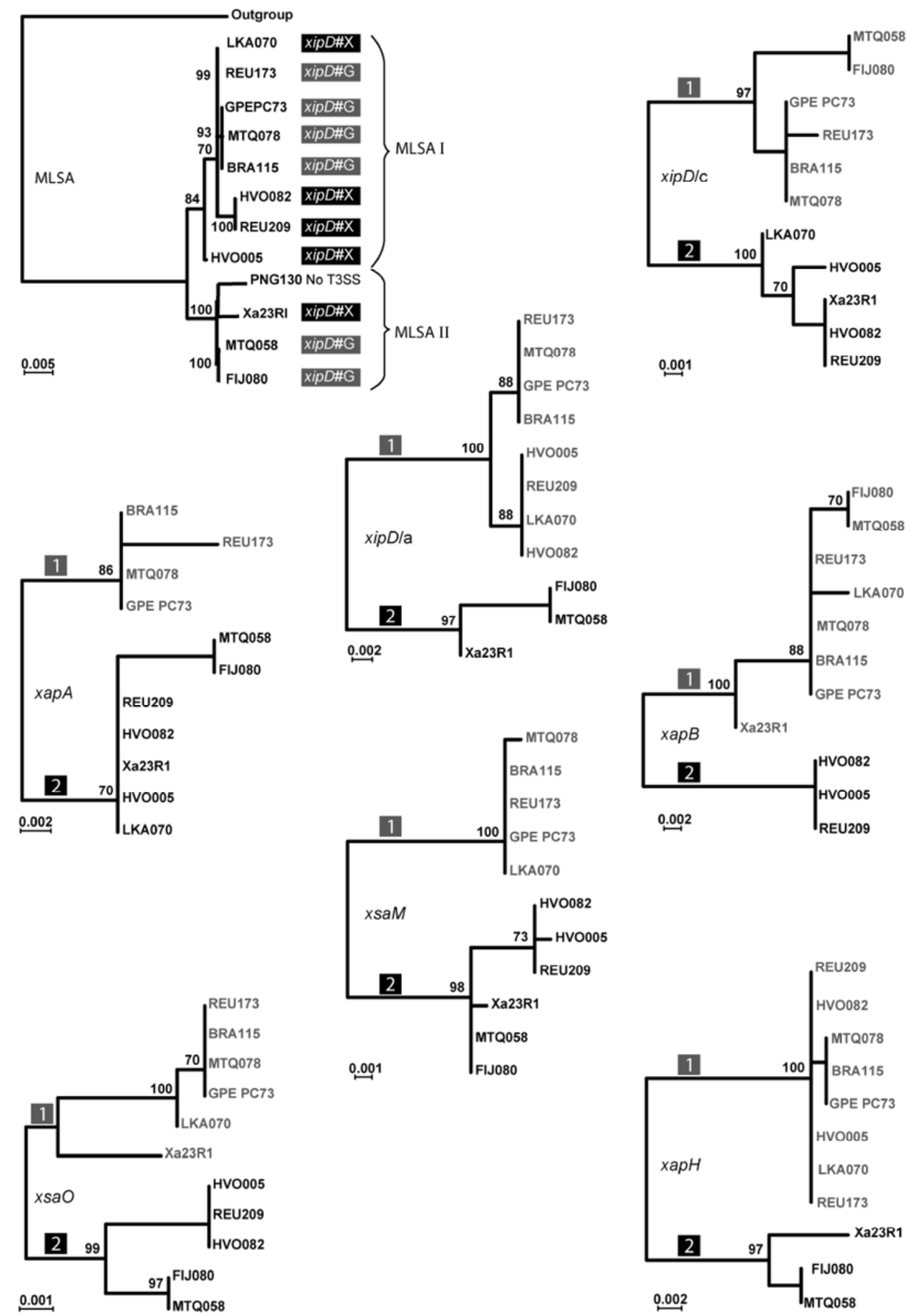

Fig. 4. Phylogenetic trees of Xanthomonas albilineans based on sequences of 11 or 12 strains of the pathogen. The multilocus sequence analysis tree was constructed with the concatenated nucleotide sequences of polymerase chain reaction (PCR) fragments from seven housekeeping genes (gyrB, atpD, dnaK, $e f p$, groEL, glnA, and $r e c A$ ) using the maximum likelihood method and GTR as the substitution model. The tree was constructed with X. albilineans XsaS 3 as outgroup. Strain XsaS3, which was isolated in Guadeloupe from sugarcane leaf surfaces, failed to induce symptoms in sugarcane after plant inoculation (Daugrois et al. 2003) and lacks most of the sequences identified in the complete genome sequence of GPE PC73 as being specific to X. albilineans, including type III secretion system (T3SS) Salmonella pathogenicity island 1 (SPI-1) (M. Royer, unpublished data). Bootstrap percentages retrieved in 1,000 replications and $>70 \%$ are shown at the nodes. Scale bar (0.005) indicates the number of nucleotide substitutions per site. Distribution of the two allelic forms of gene $x i p D$ ( $x i p D-G$ or $x i p D-X)$ in different strains of $X$. albilineans is indicated to the right of the tree. No PCR product was obtained with primers specific to T3SS SPI-1 for strain PNG130. Other trees were constructed with the complete or partial coding sequence of six genes from the T3SS SPI-1 gene cluster of $X$. albilineans using the maximum likelihood method and GTR as the substitution model. Trees xapA and xapB resulted from alignment of complete genes $x a p A$ and $x a p B$, respectively. Trees $x s a M, x s a O$, and $x a p H$ resulted from alignment of the partial coding sequences of genes $x s a M$, $x s a O$, and $x a p H$, respectively. Trees xipD/a and xipD/c resulted from alignment of the $5^{\prime}$ and $3^{\prime}$ part of xipD. Major clades (1 and 2) are indicated on top of the left branch of each tree (see text for details). Bootstrap percentages retrieved in 1,000 replications and $>50 \%$ are shown at the nodes. Scale bar (0.001 or 0.002 ) indicates the number of nucleotide substitutions per site. 
C Detected by

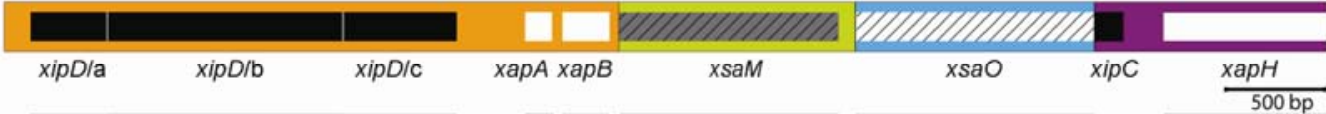

GENECONV/RDP/DNA SP GENECONV/RDP/DNA SP

CHIMAERA/DNA sP

CHIMAERA/DNA SP

GENECONV/DNA sP

GENECONV/DNA sp

RDP

GENECONV/RDP

RDPIDNA SP

GENECONVIDNA SP
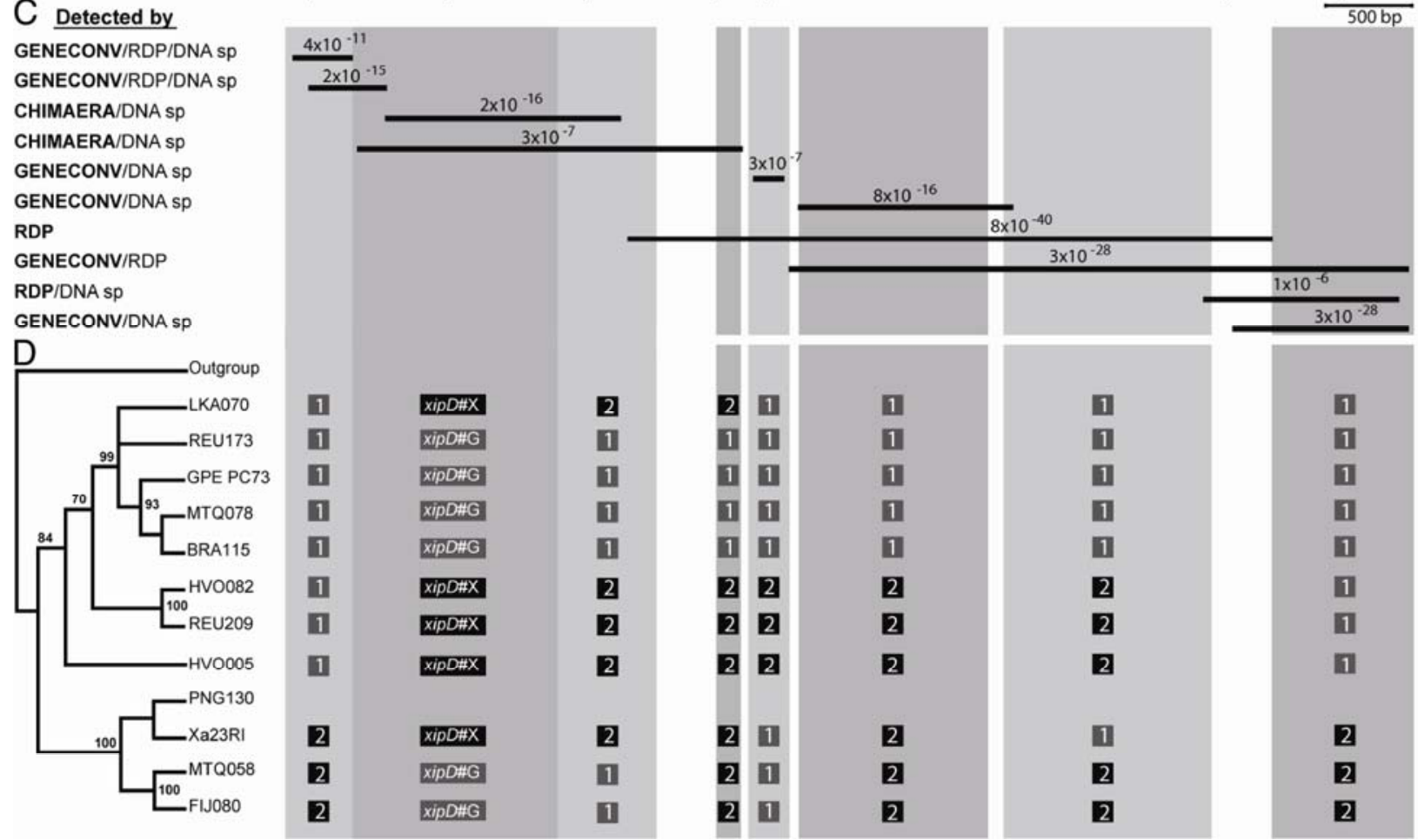

MLSA I

Fig. 5. Detection of recombination events in the type III secretion system (T3SS) Salmonella pathogenicity island 1 (SPI-1)-1 of Xanthomonas albilineans A, Genomic organization of the X. albilineans T3SS SPI-1 gene cluster. Colored boxes indicate sequences amplified by polymerase chain reaction (PCR) from $10 \mathrm{X}$. albilineans strains and retrieved from GenBank for X. albilineans GPE PC73: orange box $=$ two overlapping PCR fragments amplified by primer pairs TTSS28/XipDF and TTSS27/TTSS27bis, green box = PCR fragment amplified by primer pair TTSS20/TTSS20bis, blue box = PCR fragment amplified by primer pair TTSS18/TTSS18bis, and purple box = PCR fragment amplified by primer pair TTSS3/TTSS3bis. IS = insertion sequence, XALB1 $=$ albicidin biosynthesis gene cluster, and $\mathrm{T}=$ terminus of replication. $\mathbf{B}$, Concatenation of the five PCR fragments used for recombination analyses Concatenated sequence included coding and noncoding sequences. Names of following coding sequences are indicated below boxes: complete $x i p D$ gene (parts a, b, and c); complete $x a p A$ and $x a p B$ genes; and partial sequences of genes $x s a M$, xsaO, xipC, and $x a p H$. Scale bar $=500$ bp. C, Recombination analyses. Horizontal bars indicate recombinant regions detected in the concatenated sequence by the method listed to the left of the figure. Reported $P$ value, indicated above each bar, corresponds to the method in bold type and is the best calculated $P$ value. D, Phylogenetic analyses. The tree corresponds to the multilocus sequence analysis tree shown in Figure 4, except that branch lengths are not proportional to the number of nucleotide substitutions per site. Numbers 1 and 2 indicate the clade to which each strain belongs in trees obtained for each coding sequence included in the concatenated sequence. Distribution of the two allelic forms of gene $x i p D$ (xipD-G or xipD-X) in the different strains of $X$. albilineans is indicated for the coding sequence xipD/b. Vertical gray zones indicate the coding sequences used to construct each tree with the corresponding clade.

Table 2. Nonsynonymous to synonymous $\left(\mathrm{d}_{\mathrm{N}} / \mathrm{d}_{\mathrm{S}} ; \omega\right)$ ratio estimates and likelihood ratio tests of coding sequences of the type III secretion system Salmonella pathogenicity island 1 (SPI-1) of Xanthomonas albilineans

\begin{tabular}{|c|c|c|c|c|c|c|c|}
\hline \multirow[b]{2}{*}{ Models $^{\mathrm{a}}$} & \multicolumn{7}{|c|}{ Coding sequences } \\
\hline & $x i p D / a$ & $x i p D / c$ & xapA & $x a p B$ & $x s a M$ & $x \mathrm{saO}$ & xapH \\
\hline \multicolumn{8}{|c|}{ Model1, $\omega=1$ (fixed) } \\
\hline $\mathrm{np}$ & 20 & 20 & 20 & 20 & 20 & 20 & 20 \\
\hline $\operatorname{Ln} L$ & -555.430 & -839.852 & -225.446 & -375.089 & $-1,591.944$ & $-1,717.916$ & $-1,188.978$ \\
\hline$\omega$ & 1 & 1 & 1 & 1 & 1 & 1 & 1 \\
\hline \multicolumn{8}{|c|}{ Model2, $\omega$ estimated } \\
\hline $\mathrm{np}$ & 21 & 21 & 21 & 21 & 21 & 21 & 21 \\
\hline $\operatorname{Ln} L$ & -552.517 & -838.822 & -224.650 & -374.677 & $-1,591.860$ & $-1,707.969$ & $-1,185.860$ \\
\hline$\omega$ & 0.252 & 0.456 & 0.248 & 1.956 & 0.826 & 0.113 & 4.552 \\
\hline$d_{N}$ & 0.020 & 0.021 & 0.018 & 0.058 & 0.022 & 0.006 & 0.043 \\
\hline $\mathrm{d}_{\mathrm{S}}$ & 0.079 & 0.045 & 0.070 & 0.029 & 0.026 & 0.051 & 0.010 \\
\hline \multicolumn{8}{|c|}{ LRT model1 vs. model 2} \\
\hline $2 \Delta \operatorname{Ln} L$ & 5.828 & 2.060 & 1.590 & 0.825 & 0.167 & 19.894 & 6.236 \\
\hline df & 1 & 1 & 1 & 1 & 1 & 1 & 1 \\
\hline$P$ value & 0.0158 & 0.1512 & 0.2073 & 0.3638 & 0.6825 & $8.18 \mathrm{E}-06$ & 0.0125 \\
\hline Significance $^{b}$ & $*$ & NS & NS & NS & NS & $* *$ & $*$ \\
\hline
\end{tabular}

${ }^{\text {a }} \operatorname{Ln} L, \log$-likelihood of the model; np, number of parameters of the model; $2 \Delta \operatorname{Ln} L$, twice the likelihood of the two compared models; df, number of degree of freedom; LRT, likelihood ratio test.

${ }^{\mathrm{b}}$ Significance:* and $* *=$ significant at the 5 and $0.1 \%$ level, respectively; NS $=$ not significant. 
T3SS SPI-1 evolved under positive selection $(P$ values obtained for genes other than $x a p H$ were not significant: $0.662<P$ value $<1.000$ ), thus confirming that averaged $\omega$ estimations were not biased by overestimation.

\section{DISCUSSION}

Recent sequencing of the genome of the sugarcane leaf scald pathogen $X$. albilineans GPE PC73 revealed the presence of a complete T3SS SPI-1 gene cluster (Pieretti et al. 2009). Data described herein reveal that this complete gene cluster is also present in $X$. albilineans Xa23R1, which belongs to another MLSA group. This T3SS SPI-1, which shows low similarity with other T3SS SPI-1 sequences available in data libraries, encodes a translocase protein, XipD (= SipD), exhibiting a unique and large additional sequence. A collection of 128 strains belonging to the main genera of plant-pathogenic bacteria, including 42 species of Xanthomonas to ensure that the genetic diversity of this genus was fully represented, was screened for the presence of the T3SS SPI-1 gene cluster of $X$. albilineans. This gene cluster was found in only two phylogenetically distant species of Xanthomonas: $X$. albilineans and $X$. axonopodis pv. phaseoli. Interestingly, the T3SS SPI-1 was not found in $X$. transluscens and $X$. hyacinth - the two species most related to $X$. albilineans according to a phylogenetic study based on 1,314 amplified fragment length polymorphism markers (Bui Thi Ngoc et al. 2010).

The presence of the same T3SS SPI-1 in two species of Xanthomonas ( $X$. albilineans and $X$. axonopodis) raises the question of the origin of this gene cluster. Did these species share the same ecological niche and exchange genetic material? Did these species acquire T3SS SPI-1 independently from the same bacterium? Was a T3SS SPI-1 present in the ancestor of the genus Xanthomonas but subsequently lost by most Xanthomonas spp.? The lack of PCR detection of xipD and candidate T3SEs genes in $X$. axonopodis pv. phaseoli may be due to polymorphism between the two species of Xanthomonas at the level of these genes. Sequencing of the complete genome of a $X$. axonopodis pv. phaseoli strain harboring T3SS SPI-1 should allow some conclusions to be drawn about the maintenance or degradation of this gene cluster in this species.

The flanking regions of the complete T3SS SPI-1 are identical in strains GPE PC73 and Xa23R1, indicating the occurrence of a single integration event of T3SS SPI-1 in the genome of the common ancestor of all $X$. albilineans strains. However, phylogenetic and recombination analyses clearly indicate that several recombination events have occurred between two alleles of the same T3SS SPI-1 gene cluster in ancestors of $X$. albilineans strains. No remains of a second copy of the T3SS SPI1 gene cluster were found in the genome sequence of $X$. albilineans GPE PC73, and none were amplified by PCR in other strains. Therefore, in order for these recombination events to have occurred, a second copy of T3SS SPI-1 must have been present in ancestors of $X$. albilineans strains, either on a nonreplicative DNA molecule (hypothesis 1) or on an ancestral plasmid (hypothesis 2) that was subsequently lost. According to hypothesis 1, multiple lateral gene transfers of T3SS SPI-1 must have occurred either between ancestors of $X$. albilineans strains themselves or between ancestors of $X$. albilineans strains and an unknown bacterium living in the same environment and possessing the same T3SS SPI-1. According to hypothesis 2, the occurrence of recombination events in both MLSA I and MLSA II groups supposes that the plasmid harboring a second copy of T3SS SPI-1 was lost only after the divergence of strains LKA070 and Xa23R1, implying that this plasmid was maintained by ancestors of $X$. albilineans strains.

Table 3. Detection of positive selection in the analyzed coding sequences of the type III secretion system Salmonella pathogenicity island 1 (SPI-1) of Xanthomonas albilineans ${ }^{\mathrm{a}}$

\begin{tabular}{|c|c|c|c|c|c|c|c|c|}
\hline $\begin{array}{l}\text { Sequence } \\
\text { model, LRT }\end{array}$ & $\operatorname{Ln} L$ & np & $\omega$ Max & Percent & $2 \Delta \operatorname{Ln} L$ & df & $P$ & Sig \\
\hline \multicolumn{9}{|l|}{$x i p D / a$} \\
\hline M7 & -552.518 & 22 & $\ldots$ & $\ldots$ & \multirow[t]{3}{*}{$\ldots$} & $\ldots$ & $\ldots$ & $\ldots$ \\
\hline M8 & -552.519 & 24 & $\ldots$ & $\ldots$ & & $\ldots$ & $\ldots$ & $\ldots$ \\
\hline LRT & $\ldots$ & $\ldots$ & $\ldots$ & $\ldots$ & & 2 & 1.000 & NS \\
\hline \multicolumn{9}{|l|}{$x i p D / c$} \\
\hline M7 & -838.823 & 22 & $\ldots$ & $\ldots$ & $\ldots$ & $\ldots$ & $\ldots$ & $\ldots$ \\
\hline M8 & -838.823 & 24 & 1.000 & 0.00001 & $\ldots$ & $\ldots$ & $\ldots$ & $\ldots$ \\
\hline LRT & $\ldots$ & $\ldots$ & $\ldots$ & $\ldots$ & $3.000 \mathrm{E}-05$ & 2 & 1.000 & NS \\
\hline \multicolumn{9}{|l|}{ харА } \\
\hline M7 & -224.651 & 22 & $\ldots$ & $\ldots$ & $\ldots$ & $\ldots$ & $\ldots$ & $\ldots$ \\
\hline M8 & -224.651 & 24 & 1.000 & 0.00001 & $\ldots$ & $\ldots$ & $\ldots$ & $\ldots$ \\
\hline LRT & $\ldots$ & $\ldots$ & $\ldots$ & $\ldots$ & $1.540 \mathrm{E}-04$ & 2 & 1.000 & NS \\
\hline \multicolumn{9}{|l|}{$x a p B$} \\
\hline M7 & -375.089 & 22 & $\ldots$ & $\ldots$ & $\ldots$ & $\ldots$ & $\ldots$ & $\ldots$ \\
\hline M8 & -374.677 & 24 & $\ldots$ & $\ldots$ & $\ldots$ & $\ldots$ & $\ldots$ & $\ldots$ \\
\hline LRT & $\ldots$ & $\ldots$ & $\ldots$ & $\ldots$ & $8.248 \mathrm{E}-01$ & 2 & 0.662 & NS \\
\hline \multicolumn{9}{|l|}{ xsaM } \\
\hline M7 & -1591.837 & 22 & $\ldots$ & $\ldots$ & $\ldots$ & $\ldots$ & $\ldots$ & $\ldots$ \\
\hline M8 & -1591.793 & 24 & 1.839 & 0.473 & $\ldots$ & $\ldots$ & $\ldots$ & $\ldots$ \\
\hline LRT & $\ldots$ & $\ldots$ & $\ldots$ & $\ldots$ & 8.792E-02 & 2 & 0.957 & NS \\
\hline \multicolumn{9}{|l|}{$x \mathrm{saO}$} \\
\hline M7 & -1707.970 & 22 & $\ldots$ & $\ldots$ & $\ldots$ & $\ldots$ & $\ldots$ & $\ldots$ \\
\hline M8 & -1707.970 & 24 & 1.000 & 0.00001 & $\ldots$ & $\ldots$ & $\ldots$ & $\ldots$ \\
\hline LRT & $\ldots$ & $\ldots$ & $\ldots$ & $\ldots$ & 4.460E-04 & 2 & 0.999 & NS \\
\hline \multicolumn{9}{|l|}{ харH } \\
\hline M7 & -1188.978 & 22 & $\ldots$ & $\ldots$ & $\ldots$ & $\ldots$ & $\ldots$ & $\ldots$ \\
\hline M8 & -1185.860 & 24 & 4.552 & 1.000 & $\ldots$ & $\ldots$ & $\ldots$ & $\ldots$ \\
\hline LRT & $\ldots$ & $\ldots$ & $\ldots$ & $\ldots$ & 6.24 & 2 & 0.044 & $*$ \\
\hline
\end{tabular}


Interestingly, phylogenetic analyses of the T3SS Hrp gene clusters of Pseudomonas syringae or enterobacterial plant pathogens (Erwinia, Brenneria, Pectobacterium, Dickeya, and Pantoea spp.) also revealed conflicts between phylogenetic trees constructed with different genes of the same T3SS Hrp gene cluster (Guttman et al. 2006; Naum et al. 2009). Recombination events between the conserved copy of the T3SS Hrp gene cluster of Pseudomonas syringae and an ancestral lost copy was proposed to explain these conflicts (Guttman et al. 2006). Extensive lateral gene transfer of T3SS Hrp genes among enterobacterial plant pathogens was proposed to explain the occurrence of multiple recombination events (Naum et al. 2009). As in the case of the T3SS SPI-1 of $X$. albilineans, phylogenetic analyses of the T3SS Hrp of Pseudomonas syringae indicated that recombination events mobilized only two ancestral alleles. Interpretations of phylogenetic analyses of T3SS Hrps of enterobacterial plant pathogens are more complicated, probably because multiple recombination events mobilized multiple alleles.

Shigellae and enteroinvasive Escherichia coli both contain a virulence plasmid harboring a full T3SS SPI-1 (Buchrieser et al. 2000; Venkatesan et al. 2001). X. albilineans could have acquired a similar plasmid harboring a T3SS SPI-1, possibly by lateral gene transfer. In a second step, this T3SS SPI-1 could have been integrated into the chromosome of $X$. albilineans near the terminus of replication. Acquisition of genes by lateral gene transfer at the terminus of replication has been described in other bacteria. In Bacillus subtilis, the presence of a large $\mathrm{SPb}$ prophage at the terminus of replication has caused lateral gene transfer (Kunst et al. 1997). Similarly, in E. coli, lambdoid prophages tend to cluster close to the terminus of replication (Campbell 1992), and it has been suggested recently that hyper-recombination in the $E$. coli terminus region is due largely to these prophage sequences (Corre et al. 2000). Interestingly, the $X$. albilineans replication terminus region contains seven phage-related coding sequences (CDS) that are orthologous of CDS present in a filamentous prophage $\mathrm{Cf1C}$ close to the terminus of replication in other Xanthomonas spp. The presence of these phage sequences probably caused hyperrecombination and facilitated integration of the full T3SS SPI1 and the albicidin biosynthesis gene cluster. The presence of these phage sequences may indicate that the full T3SS SPI-1 and the albicidin biosynthesis gene cluster were acquired by lateral gene transfer.

Despite the occurrence of several recombination events, no nonsense mutations or frameshifting indels were observed in the five PCR fragments from nine $X$. albilineans strains or in the complete sequence of T3SS SPI-1 from strains GPE PC73 and Xa23R1, supporting the hypothesis that T3SS SPI-1 is maintained in $X$. albilineans. Inoculation of sugarcane with knockout mutants showed clearly that the T3SS SPI-1 of X. albilineans is not required for sugarcane xylem colonization and symptom development by the pathogen. This result is in agreement with the absence of the T3SS SPI-1 in strain PNG130 of $X$. albilineans, which is pathogenic to sugarcane. Alternatively, the T3SS SPI-1 may be required for interaction with an insect or animal host. An interaction of $X$. albilineans with an insect could have played or possibly could still play an important role in the dissemination of this bacterium, as is the case for $X y$ lella fastidiosa. Various sap-feeding insects can acquire and transmit $X$. fastidiosa - a xylem-limited bacterium that causes Pierce's disease of grapevine and other important plant diseases (Chatterjee et al. 2008). Interestingly, X. albilineans and Xylella fastidiosa are derived from the same ancestor, and experienced convergent genome erosion during their descent from the progenitor of the Xanthomonas genus (Pieretti et al. 2009). A similar insect-associated lifestyle may have favored such genome erosion because most genes required for a plant-associated lifestyle are most likely not required for an insect-associated lifestyle (Pieretti et al. 2009). Furthermore, the chiA gene recently characterized as required by $X$. fastidiosa to use chitin of insect hosts as a source of carbon (Killiny et al. 2010) is also present in the genome of X. albilineans. However, Xylella fastidiosa lacks any T3SS, showing that T3SS SPI-1 is not necessarily required for insect transmission.

Selection analysis indicated that purifying selection has driven the evolution of xipD and $x s a O$. Further analyses will be necessary to determine whether purifying selection also drove evolution of the entire T3SS SPI- 1 gene cluster. Interestingly, most synonymous mutations in $x s a O$ and $x i p D / a$ were acquired by recombination (Supplementary Table 4), indicating that the variability in T3SS SPI-1 revealed in this study corresponds to the variability of the two allelic forms of T3SS SPI-1. According to hypothesis 1 (multiple lateral genetic transfer of T3SS SPI-1), this variability could reflect evolution of T3SS SPI-1 either in two ancestors of $X$. albilineans or in the unknown bacterium harboring T3SS SPI-1 living in the same environment. According to hypothesis 2 (plasmid-borne second copy of T3SS SPI-1), this variability might reflect coevolution of two copies of the same T3SS SPI-1 in the common ancestor of $X$. albilineans strains. Consequently, the T3SS SPI-1 should be considered to be a system involved in the lifecycle of $X$. albilineans or in the lifecycle of the unknown bacterium occupying the same environment as $X$. albilineans.

Selection analysis also indicated that diversifying selection drove the evolution of $x a p H$ which, like other hypothetical protein genes specific to the T3SS SPI-1 of $X$. albilineans, is proposed to encode a T3SE. The proposed function of $x a p H$ is compatible with diversifying selection acting on this gene, which may prevent detection of the T3SE by animal immune systems.

Both allelic forms of xipD probably conserved the function of T3SS translocase because they harbor the same 3' part, which is similar to the translocase genes bipD and sipD of Burkholderia and Salmonella spp., respectively. The translocase protein SipD was described as being involved in the attachment of Salmonella enterica sv. typhimurium to animal host cells (Lara-Tejero and Galan 2009). Similarly, the two allelic forms of xipD may be involved in attachment to two different types of animal cells. According to hypothesis 1 (multiple lateral genetic transfer), selection of one of the two allelic forms of xipD may be linked to an adaptation of $X$. albilineans strains to attachment to only one type of animal cell. According to hypothesis 2 (plasmid harboring a second copy of T3SS SPI-1), maintenance of the two allelic forms of xipD in the ancestor of $X$. albilineans may be linked to association with an animal or insect host involving attachment to these two different types of cells.

Demonstration of in vitro expression of T3SS SPI-1 genes could provide further evidence for the functional maintenance of this secretion system in $X$. albilineans. However, reverse-transcription PCR assays with primers specific for xipD, xsaO, or $x s a M$ failed to show any transcription of T3SS SPI-1 in X. albilineans GPE PC73 grown in a rich medium (M. Royer, unpublished data). Furthermore, transformation with plasmids harboring a bidirectional promoter located between genes $x s a N$ and $x s a M$ fused in both orientations to a green fluorescent protein gene failed to yield any fluorescing bacteria in $X$. albilineans GPE PC73 grown in minimal and rich medium supplemented with different samples prepared from sugarcane leaves, mice, insects, or primate- or insect-cell cultures (M. Royer, unpublished data).

To conclude, phylogenetic, recombination, and selection analyses all concur that the T3SS SPI-1 is maintained within the species $X$. albilineans, although this gene cluster is absent in 
strain PNG130 and is not required for xylem colonization and symptom development in sugarcane. T3SS SPI-1 may play an important role in association with an insect or animal host or in the ecology of $X$. albilineans. PCR screening for the presence of $X$. albilineans in insects collected recently in sugarcane fields in Guadeloupe failed to identify any insect host for this sugarcane pathogen thus far (M. Royer, unpublished data). Further surveys of insects or animals may be necessary to identify candidate hosts and to shed light on the function of T3SS SPI-1 in X. albilineans. T3SS SPI-1 PCR screening of bacteria, including endophytic and uncultivable bacteria, living in the xylem of sugarcane may also help determine the origin of the T3SS SPI- 1 in $X$. albilineans and X. axonopodis pv. phaseoli.

\section{MATERIALS AND METHODS}

\section{Bacterial strains.}

The $12 X$. albilineans strains used in this study originated from the collection of plant-pathogenic bacteria of the Centre de Coopération Internationale en Recherche Agronomique pour le Développement (CIRAD) (Montpellier, France) and are representative of the genetic diversity of $X$. albilineans. Eleven strains were previously described (Renier et al. 2007) and one-GPE PC73 (group PFGE B)—was recently sequenced (Pieretti et al. 2009). Strain GPE PC73 R5 is a spontaneous rifampicin-resistant strain derived from GPE PC73. Strains were grown for $48 \mathrm{~h}$ on modified Wilbrink's medium (Rott et al. 1994) or on XAS selective growth medium (Davis et al. 1994) at $28^{\circ} \mathrm{C}$ before use.

\section{Construction of $x \mathrm{saO}$ mutants.}

A 698-bp fragment of gene $x s a O$ was amplified with $x s a O$ primers from strain GPE PC73 and cloned into pCR4-TOPO (Invitrogen, Carlsbad, CA, U.S.A.), yielding pTOPO-xsaO. An XhoI/SpeI fragment of pTOPO-xsaO containing the $x \mathrm{saO}$ fragment was then transferred into vector pVO155 (Oke and Long 1999), yielding pVO155-xsaO. Plasmid pVO155-xsaO was then introduced into $X$. albilineans GPE PC73R5 by triparental conjugation using pRK2073 as described by Royer and associates (2004). Transformants were plated on Wilbrink agar plates supplemented with rifampicin at $50 \mathrm{mg} /$ liter and kanamycin at $20 \mathrm{mg} /$ liter. Plates were incubated at $28^{\circ} \mathrm{C}$ and mutants that grew within 5 to 7 days were screened with $x s a O$-screen primers, which consisted of one primer specific for pVO155 and one primer upstream of the fragment of $x \mathrm{saO}$ used to construct the mutant.

\section{Inoculation of sugarcane with $X$. albilineans and determination of stalk colonization.}

Pathogenicity experiments were conducted at CIRAD in an S3 containment facility using healthy plants of sugarcane cv. CP68-1026, which is susceptible to leaf scald. Inoculum of $X$. albilineans was prepared from 5-day-old agar cultures on $\mathrm{XaPR}$ medium (sucrose at $10 \mathrm{~g} / \mathrm{liter}, \mathrm{CaCl}_{2}\left[\mathrm{H}_{2} \mathrm{O}\right]$ at $5 \mathrm{mg} / \mathrm{liter}$, ferric ammonium citrate $\left[\mathrm{C}_{6} \mathrm{H}_{8} \mathrm{O}_{7} \cdot x \mathrm{Fe}_{3}{ }^{+} \cdot y \mathrm{NH}_{3}\right]$ at 50 $\mathrm{mg} / \mathrm{liter}, \mathrm{NH}_{4} \mathrm{Cl}$ at $1 \mathrm{~g} / \mathrm{liter}, \mathrm{MgSO}_{4}\left[7 \mathrm{H}_{2} \mathrm{O}\right]$ at $0.5 \mathrm{~g} /$ liter, DLmethionine at $0.1 \mathrm{~g} / \mathrm{liter}$, and agar at $15 \mathrm{~g} / \mathrm{liter}$; $\mathrm{pH}$ adjusted to 6.8 with a volume-to-volume solution of $\mathrm{Na}_{2} \mathrm{HPO}_{4}\left[12 \mathrm{H}_{2} \mathrm{O}\right]$ and $\mathrm{KH}_{2} \mathrm{PO}_{4}$ at $1 / 15 \mathrm{M}$ ). Six sugarcane stalks with at least four to five internodes were inoculated per strain with bacterial suspension at $10^{8} \mathrm{CFU} / \mathrm{ml}$ in sterile distilled water by the decapitation method as described by Rott and associates (1997). Leaf scald symptoms were recorded on three emerging leaves 1 month after inoculation. Stalk colonization by $X$. albilineans was determined by the stalk blot inoculation technique in three to four upper internodes that had grown 4 months after inoculation. Stalks were sampled individually and cut at the soil level with pruning shears. The rind of stalk fragments was cleaned with absorbent paper and flamed with alcohol to ensure external sterilization. Each stalk location was then cut transversally, in the middle, with sterile pruning shears. Cut sections were pressed firmly onto two plates of XAS selective growth medium supplemented with rifampicin at $50 \mathrm{mg} / \mathrm{liter}$ for stalks inoculated with wild-type strain GPE PC73 R5, and on XAS selective growth medium supplemented with rifampicin at $50 \mathrm{mg} / \mathrm{liter}$ and kanamycin at $20 \mathrm{mg} / \mathrm{liter}$ for stalks inoculated with $x \mathrm{saO}$ mutant strains of $X$. albilineans. Pruning shears were flamed with alcohol after each cut. Growth of $X$. albilineans was recorded after incubating the agar plated for 5 days at $28^{\circ} \mathrm{C}$.

\section{Design of PCR primers.}

The 35 primer pairs used for amplification of the T3SS SPI1 gene cluster were designed using the tool Primer 3. Primers were designed based on the sequence of the T3SS SPI-1 of strain GPE PC73 (GenBank accession no. FP565176), and 35 overlapping DNA fragments of 1.2 to $1.9 \mathrm{~kb}$ were defined. Primer pairs used for amplification of fragments of seven housekeeping genes (gyrB, groEL, recA, dnaK, efp, atpD, and $g \ln A$ ) were designed manually and validated using the Integrated DNA Technologies melting temperature calculator.

\section{PCR conditions.}

DNA templates were prepared by suspending a freshly grown colony in $100 \mu \mathrm{l}$ of sterile nuclease-free water. PCR amplifications were performed in an automated thermal cycler PTC-100 (MJ Research, Inc., Watertown, MA, U.S.A.). The 25- $\mu$ l PCR reaction mix consisted of $3 \mu \mathrm{l}$ of bacterial suspension, $2.5 \mu \mathrm{l}$ of $10 \times \mathrm{PCR}$ buffer without $\mathrm{MgCl}_{2}$ (Sigma-Aldrich, St. Louis), $120 \mu \mathrm{M} d N T P$ mix, $2.0 \mathrm{mM} \mathrm{MgCl}_{2}$ (SigmaAldrich), $0.36 \mu \mathrm{M}$ each primer, 1 unit of Taq DNA Polymerase (Sigma-Aldrich), and sterile nuclease-free water to final volume. The PCR program was $94^{\circ} \mathrm{C}$ for $4 \mathrm{~min} ; 30$ cycles at $94^{\circ} \mathrm{C}$ for $30 \mathrm{~s}$, melting temperature for $1 \mathrm{~min} 30 \mathrm{~s}$, and $72^{\circ} \mathrm{C}$ for 1 min; with a final $72^{\circ} \mathrm{C}$ extension for $8 \mathrm{~min}$. A 5 - $\mu$ l aliquot of each amplified product was analyzed by electrophoresis through a $1 \%$ agarose gel.

\section{DNA sequencing.}

DNA sequencing was performed by Beckman Coulter Genomics (Takely, U.K.). PCR fragments were sequenced with the primers used for their amplification. Sequences were aligned using ClustalW implemented in Bioedit software version 2 (ClustalW2) and corrected manually as necessary.

\section{Phylogenetic analyses.}

The phylogenetic T3SS SPI-1 tree was reconstructed using the maximum likelihood method implemented in the PhyML program. The LG substitution model was selected, assuming an estimated proportion of invariant sites (of 0.01) and four gamma-distributed rate categories to account for rate heterogeneity across sites. The six loci analyzed (InvC/XsaS, InvE/SpaP/XsaP, InvA/XsaQ, SpaQ/XsaX, SpaS/XsaZ, and SpaR/XsaY) are the same six T3SS SPI-1 structural proteins used in previous phylogenetic analysis (Degnan et al. 2009). Multiple alignments of the amino acid sequences of the six structural proteins and for all taxa were performed using ClustalW. The phylogenetic tree was calculated with PhyML version 2.4.4 (Guindon and Gascuel 2003). Five hundred bootstrap replicates were performed with PhyML program.

The phylogenetic core genome MLSA tree was reconstructed using the maximum likelihood method implemented in the PhyML program. The GTR substitution model was selected assuming an estimated proportion of invariant sites (of 0.01) 
and four gamma-distributed rate categories to account for rate heterogeneity across sites. The gamma shape parameter was estimated directly from the data $(\alpha=0.011)$. One thousand bootstrap replicates were performed with the PhyML program. The seven analyzed loci ( $g y r B$, groEL, recA, dnaK, efp, atpD, and $\operatorname{g} \ln A$ ) are typical housekeeping genes in the chromosome of $X$. albilineans GPE PC73, located 0.004, 0.348, 1.369, 1.983, $2.245,3.442$, and $3.655 \mathrm{Mb}$, respectively, from the origin of replication. The total length of the partial CDS nucleotide sequences concatenated for each taxon was 3,972 bp. Multiple alignments of the nucleotide sequences of the seven housekeeping fragment genes and for all taxa were performed using ClustalW.

Phylogenetic trees were also constructed from several complete or partial coding sequences of the locus T3SS SPI-1 of $X$. albilineans with the same methods used to construct the MLSA tree. PCR fragments used to construct these phylogenetic SPI-1 trees or the phylogenetic core genome MLSA tree were obtained from the same samples of DNA templates. Additional PCR controls were performed with other samples of the same DNA templates to rule out accidental mixing of samples.

\section{Recombination analyses.}

DnaSP (current released version: 5.10.01) (Librado and Rozas 2009) and the Recombination Detection Program (RDP3) version 3 were used to detect potential recombinant sequences and localize possible recombination breakpoints in multiple sequence alignments. RDP3 is a Windows interface for a range of different recombination detection and analysis programs, including the RDP method (Martin et al. 2005), GENECONV (Padidam et al. 1999), and CHiMAERA (Posada and Crandall 2001) methods used in this study. Analyses were performed with default settings for all detection methods.

\section{Selection analyses.}

Estimation of the ratio $\omega=\mathrm{d}_{\mathrm{N}} / \mathrm{d}_{\mathrm{S}}$ was performed using the branch models of the codeml program implemented in PAML 4.3 (Yang 1997, 1998). The likelihood (L) of each model was estimated by PAML. i) To test whether two clades in a given phylogeny underwent distinct selective pressures, a null model assuming a common $\omega$ ratio for both clades was compared with an alternative model assuming one $\omega$ ratio per clade. The two models were then compared statistically by LRT. The test statistics $2 \Delta \operatorname{lnL}$ (twice the difference of the log-likelihood between the two models) was compared with a $\chi^{2}$ distribution with $n$ degrees of freedom, $n$ being the difference between the numbers of parameters of the two models. ii) To test whether a gene evolved under purifying selection $(\omega<1)$ or evolved neutrally $(\omega=1)$, the null model assuming a fixed $\omega=1$ was compared using LRT to an alternative model with an estimated $\omega$ ratio. Positive selection was detected with codon models of the program codeml (PAML) (Yang 1998; Yang and Nielsen 1998). A neutral model (M7), using a discrete $\beta$ distribution (range $[0,1]$ ) to model different $\omega$ ratios among sites, was compared by LRT to an alternative model (M8) assuming a supplementary class of codons with $\omega>1$ ( $\omega$ estimated). Comparison of evolutionary rates between two clades of a given evolutionary tree was assessed by using the program baseml of PAML. A neutral model assuming that the two given clades evolved at the same evolutionary rate was compared by LRT with an alternative local clock model (Yang and Yoder 2003; Yoder and Yang 2000) that assumed that each clade or subclade had its own evolutionary rate.

\section{Screening of plant-pathogenic bacteria for the presence of the T3SS SPI-1 gene cluster of $X$. albilineans.}

A collection of 128 strains belonging to the main genera of plant-pathogenic bacteria (Acidovorax, Agrobacterium, Burk- holderia, Clavibacter, Curtobacterium, Erwinia, Dickeya, Herbaspirillum, Pseudomonas, Pectobacterium, Ralstonia, Xanthomonas, and Xylophilus) was screened by PCR with the primer pairs BSA Q, J, and M (based on the three DNA fragments subtracted from $X$. axonopodis pv. phaseoli) (Alavi et al. 2008) and dot-blot hybridizations as described previously (Hajri et al. 2009).

The 35 primer pairs used to amplify the complete T3SS SPI1 from $X$. albilineans Xa23R1 were used to reveal whether this gene cluster is fully or partially present in $X$. axonopodis pv. phaseoli strains. The amplified PCR products from three $X$. axonopodis pv. phaseoli strains (CFBP 2534, CFBP 6164, and CFBP 6982) were purified from agarose gels with a NucleospinH extract II kit (Macherey-Nagel EURL, Hoerdt, France) and sequenced by the Genoscreen genomic analysis platform (Lille, France).

\section{ACKNOWLEDGMENTS}

We thank E. Fournier and P. Roumagnac for fruitful discussions, H. Rothnie for English editing, and anonymous reviewers for valuable suggestions to improve the manuscript. M. Marguerettaz was supported by a Ph.D. Fellowship from La Région Languedoc-Roussillon and P. Rott was supported by a Marie Curie Outgoing International Fellowship from the European Commission.

\section{LITERATURE CITED}

Alavi, S. M., Sanjari, S., Durand, F., Brin, C., Manceau, C., and Poussier, S. 2008. Assessment of the genetic diversity of Xanthomonas axonopodis pv. phaseoli and Xanthomonas fuscans subsp. fuscans as a basis to identify putative pathogenicity genes and a type III secretion system of the SPI-1 family by multiple suppression subtractive hybridizations. Appl. Environ. Microbiol. 74:3295-3301.

Angot, A., Peeters, N., Lechner, E., Vailleau, F., Baud, C., Gentzbittel, L., Sartorel, E., Genschik, P., Boucher, C., and Genin, S. 2006. Ralstonia solanacearum requires F-box-like domain-containing type III effectors to promote disease on several host plants. Proc. Natl. Acad. Sci. U.S.A. 103:14620-14625.

Birch, R. 2001. Xanthomonas albilineans and the antipathogenesis approach to disease control. Mol. Plant Pathol. 2:1-11.

Buchrieser, C., Glaser, P., Rusniok, C., Nedjari, H., d'Hauteville, H., Kunst, F., Sansonetti, P., and Parsot, C. 2000. The virulence plasmid pWR100 and the repertoire of proteins secreted by the type III secretion apparatus of Shigella flexneri. Mol. Microbiol. 38:760-771.

Bui Thi Ngoc, L., Verniere, C., Jouen, E., Ah-You, N., Lefeuvre, P., Chiroleu, F., Gagnevin, L., and Pruvost, O. 2010. Amplified fragment length polymorphism and multilocus sequence analysis-based genotypic relatedness among pathogenic variants of Xanthomonas citri pv. citri and Xanthomonas campestris pv. bilvae. Int. J. Syst. Evol. Microbiol. 60:515-525.

Campbell, A. M. 1992. Chromosomal insertion sites for phages and plasmids. J. Bacteriol. 174:7495-7499.

Champoiseau, P., Rott, P., and Daugrois, J. H. 2009. Epiphytic populations of Xanthomonas albilineans and subsequent sugarcane stalk infection are linked to rainfall in Guadeloupe. Plant Dis. 93:339-346.

Chatterjee, S., Almeida, R. P. P., and Lindow, S. 2008. Living in two worlds: The plant and insect lifestyles of Xylella fastidiosa. Annu. Rev. Phytopathol. 46:243-271.

Cornelis, G. R. 2006. The type III secretion injectisome. Nat. Rev. Microbiol. 4:811-825.

Corre, J., Patte, J., and Louarn, J. -M. 2000. Prophage lambda induces terminal recombination in Escherichia coli by inhibiting chromosome dimer resolution: An orientation-dependent cis-effect lending support to bipolarization of the terminus. Genetics 154:39-48.

Correa, V. R., Majerczak, D. R., Ammar, E., Merighi, M., Pratt, R. C., Redinbaugh, M. G., Coplin, D. L., and Hogenhout, S. A. 2010. A bacterial pathogen uses distinct type III secretion systems to alternate between host kingdoms. (Abstr.) Phytopathology 100:S27.

Croxen, M. A., and Finlay, B. B. 2010. Molecular mechanisms of Escherichia coli pathogenicity. Nat. Rev. Microbiol. 8:26-38.

Daugrois, J. H., Dumont, V., Champoiseau, P., Costet, L., Boisne-Noc, R., and Rott, P. 2003. Aerial contamination of sugarcane in Guadeloupe by two strains of Xanthomonas albilineans. Eur. J. Plant Pathol. 109:445-458. 
Davis, M., Rott, P., Baudin, P., and Dean, J. 1994. Evaluation of selective media and immunoassays for detection of Xanthomonas albilineans, causal agent of sugarcane leaf scald disease. Plant Dis. 78:78-82.

Davis, M., Rott, P., Warmuth, C., Chatenet, M., and Baudin, P. 1997. Intraspecific genomic variation within Xanthomonas albilineans, the sugarcane leaf scald pathogen. Phytopathology 87:316-324.

Degnan, P. H., Leonardo, T. E., Cass, B. N., Hurwitz, B., Stern, D., Gibbs, R. A., Richards, S., and Moran, N. A. 2009. Dynamics of genome evolution in facultative symbionts of aphids. Environ. Microbiol. 12:20602069

Gerlach, R., and Hensel, M. 2007. Salmonella pathogenicity islands in host specificity, host pathogen-interactions and antibiotics resistance of Salmonella enterica. Berl. Muench. Tieraerztl. Wochenschr. 120:317327.

Guindon, S., and Gascuel, O. 2003. A simple, fast, and accurate algorithm to estimate large phylogenies by maximum likelihood. Syst. Biol. 52:696-704

Gupta, R. S. 2000. The natural evolutionary relationships among prokaryotes. Crit. Rev. Microbiol. 26:111-131.

Guttman, D. S., Gropp, S. J., Morgan, R. L., and Wang, P. W. 2006. Diversifying selection drives the evolution of the type III secretion system pilus of Pseudomonas syringae. Mol. Biol. Evol. 23:2342-2354.

Hajri, A., Brin, C., Hunault, G., Lardeux, F., Lemaire, C., Manceau, C., Boureau, T., and Poussier, S. 2009. A "repertoire for repertoire" hypothesis: Repertoires of type three effectors are candidate determinants of host specificity in Xanthomonas. PLoS One 4:e6632.

Hashimi, S. M., Wall, M. K., Smith, A. B., Maxwell, A., and Birch, R. G. 2007. The phytotoxin albicidin is a novel inhibitor of DNA gyrase. Antimicrob. Agents Chemother. 51:181-187.

He, S. Y., Nomura, K., and Whittam, T. S. 2004. Type III protein secretion mechanism in mammalian and plant pathogens. Biochim. Biophys. Acta 1694:181-206.

Joardar, V., Lindeberg, M., Jackson, R. W., Selengut, J., Dodson, R., Brinkac, L. M., Daugherty, S. C., Deboy, R., Durkin, A. S., Giglio, M. G., Madupu, R., Nelson, W. C., Rosovitz, M. J., Sullivan, S., Crabtree, J., Creasy, T., Davidsen, T., Haft, D. H., Zafar, N., Zhou, L., Halpin, R., Holley, T., Khouri, H., Feldblyum, T., White, O., Fraser, C. M., Chatterjee, A. K., Cartinhour, S., Schneider, D. J., Mansfield, J., Collmer, A., and Buell, C. R. 2005. Whole-genome sequence analysis of Pseudomonas syringae pv. phaseolicola 1448A reveals divergence among pathovars in genes involved in virulence and transposition. J. Bacteriol. 187:6488-6498.

Kay, S., and Bonas, U. 2009. How Xanthomonas type III effectors manipulate the host plant. Curr. Opin. Microbiol. 12:37-43.

Killiny, N., Prado, S. S., and Almeida, R. P. P. 2010. Chitin utilization by the insect-transmitted bacterium Xylella fastidiosa. Appl. Environ. Microbiol. 76:6134-6140.

Kube, M., Migdoll, A., Müller, I., Kuhl, H., Beck, A., Reinhardt, R., and Geider, K. 2008. The genome of Erwinia tasmaniensis strain Et1/99, a non-pathogenic bacterium in the genus Erwinia. Environ. Microbiol. 10:2211-2222.

Kube, M., Migdoll, A., Gehring, I., Heitmann, K., Mayer, Y., Kuhl, H., Knaust, F., Geider, K., and Reinhardt, R. 2010. Genome comparison of the epiphytic bacteria Erwinia billingiae and E. tasmaniensis with the pear pathogen E. pyrifoliae. BMC Genomics 11:393.

Kunst, F., Ogasawara, N., Moszer, I., Albertini, A. M., Alloni, G., Azevedo, V., Bertero, M. G., Bessieres, P., Bolotin, A., Borchert, S., Borriss, R., Boursier, L., Brans, A., Braun, M., Brignell, S. C., Bron, S., Brouillet, S., Bruschi, C. V., Caldwell, B., Capuano, V., Carter, N. M., Choi, S.K., Codani, J. J., Connerton, I. F., Cummings, N. J., Daniel, R. A., Denizot, F., Devine, K. M., Dusterhoft, A., Ehrlich, S. D., Emmerson, P. T., Entian, K. D., Errington, J., Fabret, C., Ferrari, E., Foulger, D., Fritz, C., Fujita, M., Fujita, Y., Fuma, S., Galizzi, A., Galleron, N., Ghim, S. Y., Glaser, P., Goffeau, A., Golightly, E. J., Grandi, G., Guiseppi, G., Guy, B. J., Haga, K., Haiech, J., Harwood, C. R., Henaut, A., Hilbert, H., Holsappel, S., Hosono, S., Hullo, M. F., Itaya, M., Jones, L., Joris, B., Karamata, D., Kasahara, Y., Klaerr-Blanchard, M., Klein, C., Kobayashi, Y., Koetter, P., Koningstein, G., Krogh, S., Kumano, M., Kurita, K. Lapidus, A., Lardinois, S., Lauber, J., Lazarevic, V., Lee, S. M., Levine, A., Liu, H., Masuda, S., Mauel, C., Medigue, C., Medina, N., Mellado, R.P., Mizuno, M., Moestl, D., Nakai, S., Noback, M., Noone, D., O'Reilly, M., Ogawa, K., Ogiwara, A., Oudega, B., Park, S. H., Parro, V., Pohl, T. M., Portetelle, D., Porwollik, S., Prescott, A. M., Presecan, E., Pujic, P., Purnelle, B., Rapoport, G., Rey, M., Reynolds, S., Rieger, M., Rivolta, C., Rocha, E., Roche, B., Rose, M., Sadaie, Y., Sato, T. Scanlan, E., Schleich, S., Schroeter, R., Scoffone, F., Sekiguchi, J., Sekowska, A., Seror, S.J., Serror, P., Shin, B. S., Soldo, B., Sorokin, A., Tacconi, E., Takagi, T., Takahashi, H., Takemaru, K., Takeuchi, M., Tamakoshi, A., Tanaka, T., Terpstra, P., Tognoni, A., Tosato, V., Uchiyama, S., Vandenbol, M., Vannier, F., Vassarotti, A., Viari, A.,
Wambutt, R., Wedler, E., Wedler, H., Weitzenegger, T., Winters, P., Wipat, A., Yamamoto, H., Yamane, K., Yasumoto, K., Yata, K., Yoshida, K., Yoshikawa, H. F., Zumstein, E., Yoshikawa, H., and Danchin, A. 1997. The complete genome sequence of the gram-positive bacterium Bacillus subtilis. Nature 390:249-256.

Lara-Tejero, M., and Galan, J. E. 2009. Salmonella enterica serovar Typhimurium pathogenicity island 1-encoded type III secretion system translocases mediate intimate attachment to nonphagocytic cells. Infect. Immun. 77:2635-2642.

Lewis, J. D., Guttman, D. S., and Desveaux, D. 2009. The targeting of plant cellular systems by injected type III effector proteins. Semin. Cell. Dev. Biol. 20:1055-1063.

Librado, P., and Rozas, J. 2009. DnaSP v5: A software for comprehensive analysis of DNA polymorphism data. Bioinformatics 25:1451-1452.

Martin, D. P., Posada, D., Crandall, K. A., and Williamson, C. 2005. A Modified bootscan algorithm for automated identification of recombinant sequences and recombination breakpoints. AIDS Res. Hum. Retroviruses 21:98-102.

McGhie, E. J., Brawn, L. C., Hume, P. J., Humphreys, D., and Koronakis, V. 2009. Salmonella takes control: Effector-driven manipulation of the host. Curr. Opin. Microbiol. 12:117-124.

Naum, M., Brown, E. W., and Mason-Gamer, R. J. 2009. Phylogenetic evidence for extensive horizontal gene transfer of type III secretion system genes among enterobacterial plant pathogens. Microbiology 155:31873199 .

Oke, V., and Long, S. R. 1999. Bacterial genes induced within the nodule during the rhizobium-legume symbiosis. Mol. Microbiol. 32:837-849.

Padidam, M., Sawyer, S., and Fauquet, C. M. 1999. Possible emergence of new geminiviruses by frequent recombination. Virology 265:218-225.

Pieretti, I., Royer, M., Barbe, V., Carrere, S., Koebnik, R., Cociancich, S., Couloux, A., Darrasse, A., Gouzy, J., Jacques, M.-A., Lauber, E., Manceau, C., Mangenot, S., Poussier, S., Segurens, B., Szurek, B., Verdier, V., Arlat, M., and Rott, P. 2009. The complete genome sequence of Xanthomonas albilineans provides new insights into the reductive genome evolution of the xylem-limited Xanthomonadaceae. BMC Genomics 10:616.

Posada, D., and Crandall, K. A. 2001. Evaluation of methods for detecting recombination from DNA sequences: Computer simulations. Proc. Natl. Acad. Sci. U.S.A. 98:13757-13762.

Renier, A., Vivien, E., Cociancich, S., Letourmy, P., Perrier, X., Rott, P. C. and Royer, M. 2007. Substrate specificity-conferring regions of the nonribosomal peptide synthetase adenylation domains involved in albicidin pathotoxin biosynthesis are highly conserved within the species Xanthomonas albilineans. Appl. Environ. Microbiol. 73:5523-5530.

Rott, P., and Davis, M. 2000. Leaf scald. Pages 38-44 in: A Guide to Sugarcane Diseases. P. Rott, R. Bailey, J. Comstock, B. Croft, and A. Saumtally, eds. CIRAD-ISSCT, Montpellier, France.

Rott, P., Abel, M., Soupa, D., Feldman, P., and Letourmy, P. 1994. Population dynamics of Xanthomonas albilineans in sugarcane plants as determined with an antibiotic-resistant mutant. Plant Dis. 78:241-247.

Rott, P., Mohamed, I. S., Klett, P., Soupa, D., de Saint-Albin, A., Feldmann, P., and Letourmy, P. 1997. Resistance to leaf scald disease is associated with limited colonization of sugarcane and wild relatives by Xanthomonas albilineans. Phytopathology 87:1202-1213.

Royer, M., Costet, L., Vivien, E., Bes, M., Cousin, A., Damais, A., Pieretti, I., Savin, A., Megessier, S., Viard, M., Frutos, R., Gabriel, D., and Rott, P. 2004. Albicidin pathotoxin produced by Xanthomonas albilineans is encoded by three large PKS and NRPS gene present in a gene cluster also containing several putative modifying, regulatory, and resistance genes. Mol. Plant-Microbe Interact. 17:414-427.

Saddler, G., and Bradbury, J. 2005. Bergey's Manual of Systematic Bacteriology, Vol. 2. D. Brenner, N. Krieg, J. Staley, and G. Garrity, eds. Springer, New York.

Saijo, Y., and Schulze-Lefert, P. 2008. Manipulation of the eukaryotic transcriptional machinery by bacterial pathogens. Cell Host Microbe 4:9699.

Saumtally, S., Medan, H., and Autrey, L. 1996. Evolution of aerial infection of leaf scald caused by Xanthomonas albilineans (Ashby) Dowson in sugarcane. Pages 493-497 in: Proc. XXII Congress. J. Cock and T. Brekelbaum, eds. International Society of Sugarcane Technologists, Cartagena, Colombia.

Sebaihia, M., Bocsanczy, A. M., Biehl, B. S., Quail, M. A., Perna, N. T., Glasner, J. D., DeClerck, G. A., Cartinhour, S., Schneider, D. J., Bentley, S. D., Parkhill, J., and Beer, S. V. 2010. Complete genome sequence of the plant pathogen Erwinia amylovora strain ATCC 49946. J. Bacteriol. 192:2020-2021.

Smits, T. H. M., Rezzonico, F., Kamber, T., Blom, J., Goesmann, A., Frey, J. E., and Duffy, B. 2010. Complete genome sequence of the fire blight pathogen Erwinia amylovora CFBP 1430 and comparison to other Erwinia spp. Mol. Plant-Microbe Interact. 23:384-393. 
Stevens, M. P., Wood, M. W., Taylor, L. A., Monaghan, P., Hawes, P., Jones, P. W., Wallis, T. S., and Galyov, E. E. 2002. An Inv/Mxi-Spa-like type III protein secretion system in Burkholderia pseudomallei modulates intracellular behaviour of the pathogen. Mol. Microbiol. 46:649659

Venkatesan, M. M., Goldberg, M. B., Rose, D. J., Grotbeck, E. J., Burland, V., and Blattner, F. R. 2001. Complete DNA sequence and analysis of the large virulence plasmid of Shigella flexneri. Infect. Immun. 69:3271-3285.

Yang, Z. 1997. PAML: A programme package for phylogenetic analysis by maximum likelihood. Comput. Appl. Biosci. 13:555-556.

Yang, Z. 1998. Likelihood ratio tests for detecting positive selection and application to primate lysozyme evolution. Mol. Biol. Evol. 15:568573

Yang, Z., and Nielsen, R. 1998. Synonymous and nonsynonymous rate variation in nuclear genes of mammals. J. Mol. Evol. 46:409-418.

Yang, Z., and Yoder, A. D. 2003. Comparison of likelihood and Bayesian methods for estimating divergence times using multiple gene loci and calibration points, with application to a radiation of cute-looking mouse lemur species. Syst. Biol. 52:705-716.

Yoder, A. D., and Yang, Z. 2000. Estimation of primate speciation dates using local molecular clocks. Mol. Biol. Evol. 17:1081-1090.

\section{AUTHOR-RECOMMENDED INTERNET RESOURCES}

The ATGC Bioinformatics PhyML database: atgc.lirmm.fr/phyml ClustalW2 database: www.ebi.ac.uk/Tools/clustalw2/index.html DnaSP (DNA Sequence Polymorphism) website: www.ub.es/dnasp Integrated DNA Technologies database:

eu.idtdna.com/analyzer/applications/oligoanalyzer/Default.aspx

The Primer 3 website: biotools.umassmed.edu/bioapps/primer3_www.cgi Recombination Detection Program RDP3 software:

darwin.uvigo.es/rdp/rdp.html 